\title{
Developmental Changes Produced in the Retinofugal Pathways of Rats and Ferrets by Early Monocular Enucleations: The Effects of Age and the Differences between Normal and Albino Animals
}

\author{
S. O. Chan a and R. W. Guillery \\ Department of Human Anatomy, University of Oxford, Oxford OX13QX, England
}

Early monocular enucleations were done in rats, either at embryonic day 16 (E16) or on the day of birth, and the surviving uncrossed pathway was studied either at birth for some of the animals enucleated prenatally, or in the adult for all of the other animals. The uncrossed pathways were studied by using HRP as a retrograde tracer. The neonatal enucleations showed the increase of the surviving uncrossed component previously documented by others. In contrast to this, a prenatal enucleation produced a significant reduction in the surviving uncrossed pathway at birth. If these animals survived to be adults, then the surviving uncrossed pathway was slightly increased relative to normal.

We conclude that two quite distinct mechanisms have been exposed by these experiments, one acting prenatally and producing a reduction in the uncrossed pathway, and the other acting postnatally and producing an increase. The postnatal effect, which is due to a decrease of the normally occurring ganglion cell death, thus neutralizes the prenatal effect, so that the most effective demonstration of the prenatal effect is to be seen before the period of cell death (early postnatal in rats and ferrets).

The same methods were applied to prenatal ferrets at E26-E28 and, in order to see the maximum prenatal effects, the uncrossed pathways were studied at birth in all of these animals. There was a severe reduction of the uncrossed pathway throughout, and this was greatest in the animals with the earliest enucleations.

Since the uncrossed pathway in normally reared albino animals is abnormally small, the effects of an early prenatal enucleation in albino rats and ferrets were compared with the effects in normally pigmented animals in order to determine whether the early enucleation was producing an abnormality comparable to the albino abnormality. Prenatal enucleations reduced the uncrossed pathway not only in normally pigmented but also in albino neonatal rats and fer-

\footnotetext{
Received Feb. 17, 1993; revised May 21, 1993; accepted June 15, 1993.

This study was supported by the Wellcome Trust $(030351 / 1.27)$ and by a Croucher Foundation Scholarship to S.O.C. The work reported here formed a part of a D.Phil. thesis presented by S.O.C. in 1991 at Oxford. We thank Jeremy Taylor for his helpful comments on the manuscript. We also thank Brian Archer and Colin Beesley for their help in preparing the photographs, Terry Richards for the assistance in artwork, and Mary Walker, Zillah Deussen, and Mohan Masih for their technical assistance.

Correspondence should be addressed to Prof. R. W. Guillery, Department of Human Anatomy, University of Oxford, South Parks Road, Oxford OX1 3QX, England.

-Present address: Department of Anatomy, Faculty of Medicine, The Chinese University of Hong Kong, Shatin, N.T., Hong Kong.

Copyright (C) 1993 Suciety for Neuroscience $0270-6474 / 93 / 135277-17 \$ 05.00 / 0$
}

rets. Further, the characteristic position of the nasal border of the temporal retina, which is abnormal in albino animals, was unaffected by the enucleation in either the albino or the pigmented animals, except where, in ferrets, enucleations produced a complete loss of the temporal concentration of ipsilaterally projecting ganglion cells (the temporal crescent). The earlier enucleations showed a greater tendency to produce such a complete loss of the temporal crescent.

We conclude that the developmental mechanisms affected by the early enucleations are distinct from those that act to produce the albino abnormality even though both produce an abnormally small uncrossed pathway. The early enucleation probably acts at the chiasm, whereas the albino gene is likely to act in the retina.

IKey words: optic chiasm, uncrossed retinofugal pathways, binocular interactions, pathfinding, visual system, cell death]

The development of the optic chiasm is under the control of several distinct mechanisms that interact in a complex, but poorly understood manner to produce a characteristic distribution of crossed and uncrossed axons. The development of the chiasmatic pattern is controlled at minimally two, probably three distinct sites. The first is the retina, where the line that defines the nasal border of the temporal, uncrossed component (the temporal crescent) is established at an early stage (Bunt et al., 1983; Godement et al., 1987b, 1990; Colello and Guillery, 1990; Sretavan, 1990; Chalupa and Lia, 1991; Baker and Reese, 1993). The second is at the chiasm itself. When fibers that have come from the temporal retina reach the chiasm, they are closely mingled with fibers from other parts of the retina that are destined to cross (Colello and Guillery, 1990; Godement et al., 1990; Sretavan, 1990; Chan, 1991). There must, therefore, be a differential response of the growing axons to some signal or clue at the chiasmatic choice point, and evidence in support of this has recently been presented by Wizenmann et al. (1993).

A third site, relevant to the adult structure of the chiasm, is within the cell groups that receive the retinofugal fibers. Here the interactions between fibers from the two eyes play a role in the differential cell losses that occur postnatally and determine the final fiber distribution. Removal of one eye after the fibers have invaded their terminal sites produces an increase in the size of the uncrossed component from the surviving eye (Lund and Lund, 1973, 1976; Lund et al., 1973; Chalupa and Williams, 1984; Hsiao, 1984; Jeffery, 1984; Jen et al., 1984; Chan et al., 1989). This is in contrast to the effect of an enucleation done earlier, when no fibers or only a few have reached the chiasm, and none have yet invaded the terminal nuclei. Such an early 
enucleation produces a decrease in the uncrossed component, presumably through an action at the chiasm (Godement et al., 1987a; Guillery, 1989), indicating that there are two distinct types of binocular interaction playing a role in the development of the optic chiasm, with opposite effects on the size of the uncrossed component. In the first part of this article we have looked at the interaction between these two cffects.

The pathway that a retinofugal fiber will take depends not only upon the stage of development at which its retinal ganglion cell is generated (Walsh et al., 1983; Dräger, 1985; Reese and Colello, 1992; Baker and Reese, 1993), and upon the retinal locus of this cell (Stone, 1966; Dräger and Olsen, 1980; Chalupa and Lia, 1991), but also upon mechanisms that control the synthesis and packaging of ocular melanin (Sanderson et al., 1974; LaVail et al., 1978).

Knowledge of the relationship between melanin and the optic chiasm is based on evidence from albinos and other hypopigmented mutants. In these the nasal border of the temporal crescent is shifted toward the temporal pole, and the number of uncrossed retinofugal fibers is reduced. It is not known whether the primary action producing this change is in the retina or at the chiasm. Insofar as one can conclude that the abnormality is closcly related to the production, presence, or breakdown of melanin (see references above), one might be inclined to favor a retinal locus since melanin relates to the developing retina but not the chiasm. However, a chiasmatic locus cannot be excluded, and the recent production of reduced uncrossed pathways by a very early, intrauterine, removal of one eye has led one of us to suggest that the effect of the early eye removal might provide a model of the albino abnormality (Guillery, 1989).

The similarity between the effects of an early prenatal enucleation and the action of the albino gene is striking. The number of cells that have an uncrossed axon in one eye of albino mice (Dräger and Olsen, 1980; Guillery et al., 1987) is essentially the same as the number of cells that project ipsilaterally in the surviving eye of a mouse subjected to an early monocular enucleation (Godement et al., 1987a). Further, in normally pigmented ferrets, an early enucleation produces a pattern of retinogeniculate terminations that is remarkably like that seen in albino ferrets and, whereas the early enucleation has a marked effect on the terminal distribution of the retinogeniculate pathway in normally pigmented ferrets, it appears to have no such effect at all in albino ferrets (Guillery, 1989). If the enucleation can truly mimic the action of the albino gene, as might appear from these observations, then one would be led to conclude that the gene action must be at the chiasm. It would be hard to conceive of the enucleation of one eye affecting the retina of the other eye, or of two distinct mechanisms, one retinal and the other chiasmatic, producing truly comparable results.

In the first part of this article, we have explored the extent to which an enucleation can produce a faithful copy of the albino pathway in rats, and we have also looked in more detail at the extent to which an early enucleation can modify the pathways of an albino. We have used rats in the first study because their uncrossed component is larger than that of mice and because one of us has had considerable previous experience of the rat's retinofugal pathway (Chan and Jen, 1988; Chan et al., 1989). The results obtained from the rats have shown that a maximum effect of an early, prenatal enucleation is seen by studying the uncrossed pathway at birth, before the period of postnatal retinal ganglion cell loss. Since the changes produced in the rats were relatively modest, we then extended the study to ferrets in the second part of this article. The uncrossed component is larger in ferrets, and we were able to make relatively earlier enucleations.

\section{Materials and Methods}

Intrauterine surgery. Lister Hooded (pigmented) and Sprague-Dawley (albino) rats and normally pigmented and albino ferrets (Mustela putorius furo) were used. Embryonic day 0 (E0) was taken as the day on which a vaginal plug was identified in the rats. At E16.5 the pregnant rats were anesthetized with intraperitoneal pentobarbital $(40 \mathrm{mg} / \mathrm{kg}$ body weight) and the uterus was exposed through a small midline abdominal incision. The embryos could be seen through the uterine wall and the position of the eye was identified even in the albino animals. Only two animals were used, one from each uterine horn. Each was taken from the abdominal cavity, left within the uterus and oriented so that one eye faced the poorly vascularized region of the uterine wall. Then a purse-string suture was placed in the uterine wall over that eye. Care was taken to avoid damage to uterine or embryonic vessels. The cyc, together with the immediately adjacent uterine wall was then destroyed by a hand-held microcauterizer. The purse-string suture was immediately closed, the embryo returned to the abdominal cavity, and, when two embryos had been enucleated, the abdominal wall and skin were sutured and the mother was allowed to recover in a warm environment.

For the ferret experiments a female ferret, when in heat, was placed in a cage with a sexually active male for $24 \mathrm{hr}$. The end of this period was counted as E0. At about E23, pregnancy was checked by gentle abdominal palpation. Normal gestation in our colony is about $41 \mathrm{~d}$.

On E26-E28, the pregnant jill was anesthetized with xylazine $(1 \mathrm{mg} /$ $\mathrm{kg}$ ) and ketamine hydrochloride $(10 \mathrm{mg} / \mathrm{kg}$ ) given as a mixture intramuscularly and supplemented with intraperitoneal sodium pentobarbital $(13 \mathrm{mg} / \mathrm{kg})$. A midline abdominal incision was made and one conceptus exposed. A pursc-string gut suture was then placed in the uterine wall over the region of the fetal head and a soft wire loop was stitched to the uterine wall to provide support for the manipulation of the uterus during later reinsertion of the fetal head. Local anesthetic (xylocaine $2 \%$ with 1:200,000 adrenaline) was applied to the uterine surface and an incision was made inside the purse-string suture. The head was allowed to emerge and the rest of the fetus was retained within the uterus by gently tightening the suture. One eye was removed with fine forceps, the suture was loosened, the head returned to the uterus and then the suture was tightened and the uterine opening closed. Generally three or four embryos from one litter were enucleated in this manner, the abdominal and the skin wounds of the jill were closed and antibiotic $(0.5 \mathrm{ml}$ of duplocillin) was given; sterile procedures were used throughout surgery.

Labeling the optic tract in newborn animals. Normal and opcratcd rats were delivered naturally. Some litters were taken on the day of birth, and the newborn pups were anesthetized with ether. An incision was made on the right side in normal animals and on the side of the surviving eye in the experimental animals. Then, under a dissecting microscope a window was cut on the lateral side of the skull rostral to the transverse venous sinus. The dura was retracted without damaging the sinus and then the dorsolateral parts of the diencephalon were exposed by aspirating the overlying neocortex and hippocampus. Three to six small lesions were made in the lateral aspect of the diencephalon with a fine syringe needle, along a line perpendicular to the course of the optic tract. A small piece of Gelfoam that had previously been soaked in a solution of $2 \%$ wheat germ agglutinin conjugated to horseradish peroxidase (WGA-HRP; Sigma), 30\% horseradish peroxidase (HRP; Sigma, type VI), and $2 \%$ dimethylsulfoxide and air dricd (Chan ct al., 1989) was then inserted into each lesion site in order to label the lateral geniculate nucleus and optic tract unilaterally. The cortical cavity was then filled with clean Gelfoam, the skin was sutured, and the animals were kept in a warm, humid environment until the next day $(18-20 \mathrm{hr})$.

The ferrets were delivered by cesarian section on E4l after the jill had been anesthetized with xylazine and ketamine. The kits were transferred to a moist, warm chamber and the jill was killed by an overdose of sodium pentobarbital. The optic tract of the kits was then labeled unilaterally as above.

Labeling the optic tract in adult rats. Three groups of pigmented and albino animals were used. All were at least 2 months postnatal. These were normal control animals, animals enucleated prenatally, and those enucleated on the day of birth. They were anesthetized with intraperitoneal pentobarbital $(40 \mathrm{mg} / \mathrm{kg}$ body weight) and the heads fixed in a 
stereotaxic head holder. The scalp on one side was retracted, on the right for the controls and on the side of the surviving eye in the experimental animals, and then the skull was opened $5 \mathrm{~mm}$ rostral to the lambdoid suture. The dura was cut and the lateral surface of the thalamus, including the region of the optic tract, was exposed by removing the overlying neocortex and hippocampus. The optic tract was interrupted with a syringe needle and pieces of dried Gelfoam that had previously been impregnated with WGA-HRP and HRP (see above) were inserted into the cut. The lesion cavity was then filled with clean Gelfoam, the scalp was sutured, and the animals survived for $2 \mathrm{~d}$.

Monocular enucleations in newborn pups. Rat pups from several litters were anesthetized with ether, and then one eyelid was cut open and the eye was removed by careful dissection. The orbit was filled with Gelfoam, and the lid was sealed with a surgical dressing (Nobecutane aerosol, Astra). The animals recovered rapidly in a warm environment and were returned to their mother to be normally reared.

Preparation of whole-mounts and brain sections. Control and experimental animals were anesthetized (ether for the pups, pentobarbital for the adults) and were perfused through the heart with phosphate-buffered saline followed by $1 \%$ paraformaldehyde in $0.1 \mathrm{M}$ phosphate buffer $(\mathrm{pH}$ 7.4). The retina was marked in order to identify its dorsal pole and was prepared as a whole-mount, further fixed in $2 \%$ glutaraldehyde at $4^{\circ} \mathrm{C}$ for $1 \mathrm{hr}$, and flattened by a weight on a coverslip. The retinas were then reacted by the Hanker-Yates method (Hanker et al., 1977), mounted on gelatinized slides, dehydrated, cleared, and covered.

As soon as the eyes had been removed and the retinas flattened, the animals were further perfused with $1 \%$ paraformaldehyde and $1.25 \%$ glutaraldehyde in $0.1 \mathrm{M}$ phosphate buffer ( $\mathrm{pH} 7.4)$. The brains were removed, held in the same fixative for about $5 \mathrm{hr}$, and then transferred to $30 \%$ sucrose in $0.1 \mathrm{~m}$ phosphate buffer overnight. The brains were cut as coronal frozen sections at $25 \mu \mathrm{m}$ thickness, and every fourth section was reacted by the Hanker-Yates method.

In the experimental animals the lesioned orbits were carefully examined to check for ocular remnants. None was found. The complete removal of the eye was confirmed by the absence of an optic nerve on that side.

Cell counts. In the newborn and adult animals the number of labeled ipsilaterally projecting ganglion cells was counted in all retinas (see Fig. 3 ). The cells in retinas of newborns were counted under an oil immersion lens at $812.5 \times$. A grid, $150 \mu \mathrm{m} \times 150 \mu \mathrm{m}$, was moved systematically across the whole retinal surface so that all the labeled cells were counted once and no cell was counted more than once. The number of cells in each grid square was recorded on a scale outline drawing of the whole retina. A similar analysis was done on the retinas of adults, but the cells were counted under a magnification of $312.5 \times$ using a grid of $300 \times$ $300 \mu \mathrm{m}^{2}$ in area.

The nasal border of the temporal retina was drawn by eye on the retinal plots. It was drawn where the density of HRP-filled ganglion cells falls to the levels that characterize the adjacent nasal retina (see Fig. 5). Here and in the following text "nasal" retina refers to all parts of the retina, on both sides of the optic disk, nasal to the zone in which the density of ipsilaterally projecting ganglion cells is high.

In order to obtain a more accurate estimate of the position of the nasal border of the temporal retina in newborn animals, and to allow an objective comparison between animals, a straight line was drawn across each retinal plot, extending from the optic disk to the temporal margin of the temporal retina and passing perpendicular to the orientation of the border as judged by eye (see Fig. 5) and to approximately the midpoint of this border. Cell densities falling on or lying closest to this line were recorded. Any error arising from the different amounts of retinal shrinkage was corrected by expressing distances from the optic disk as a proportion of the retinal radius.

For some of the rats and ferrets the distribution of labeled cells was represented by dot diagrams. These were prepared by pooling cell counts in four adjacent grid squares, so that each dot in the diagrams (see Figs. $5,9,10$ ) represents the number of cells in a $300 \times 300 \mathrm{~mm}^{2}$ square.

Statistical analyses were made using one-tailed nonparametric MannWhitney tests.

\section{Results}

\section{General observations: evaluation of the tract label}

In all of the rats the label was largely restricted to one side, including the lateral parts of the thalamus and midbrain and adjacent undamaged cortical structures (Fig. 1). Spread of label
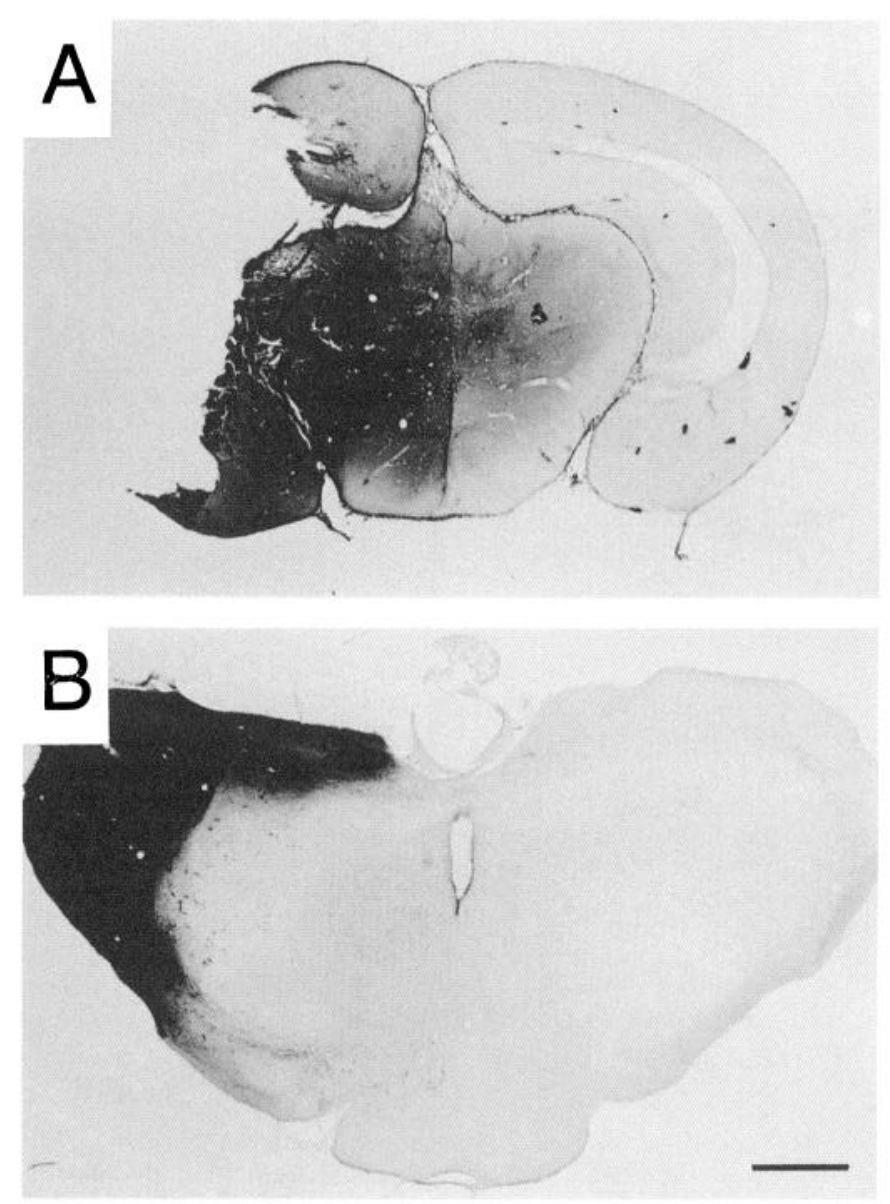

Figure 1. Coronal sections of brains from a normal newborn pigmented rat $(A)$ and an adult albino rat $(B)$ that had had one eye removed at birth. The distribution of the neuronal tracers (WGA-HRP and HRP) in the diencephalon is shown. Note that the major visual relay centers and the optic tract have been labeled on one side, and that the label has not involved the visual relays on the side opposite the injection. Scale bar, $1 \mathrm{~mm}$.

across the midline was seen in the neonatal brains but not in the adult brains. This spread in the neonatal brains never involved the optic tract or the primary visual relays of the other side. Further, none of the sections showed any labeled cells in the visual cortex on the intact side of the brain. Callosal axons had been destroyed by the cortical lesion, and corticogeniculate and corticotectal axons were not exposed to the label.

For the ferrets, Figure 2 shows two extremes of the spread of HRP. Although Figure $2 B$ shows considerable spread across the midline, this did not include the visual relay nuclei or the optic tract. Again, none of the sections showed any retrogradely labeled neurons in the visual cortex contralateral to the injection site, showing that callosal axons had been completely destroyed at the time of the operation and that the HRP did not reach the subcortical visual relay nuclei on that side of the brain.

\section{Experiments on rats}

\section{The quality of the retrograde labeling}

All newborn control rats ( 16 of 16) showed a complete and even labeling in the contralateral retina and a distinct concentration of labeled cells in the ventrotemporal part of the ipsilateral retina. The success rate for the adult controls was somewhat lower, 20 of the 25 animals showing a complete labeling in the 

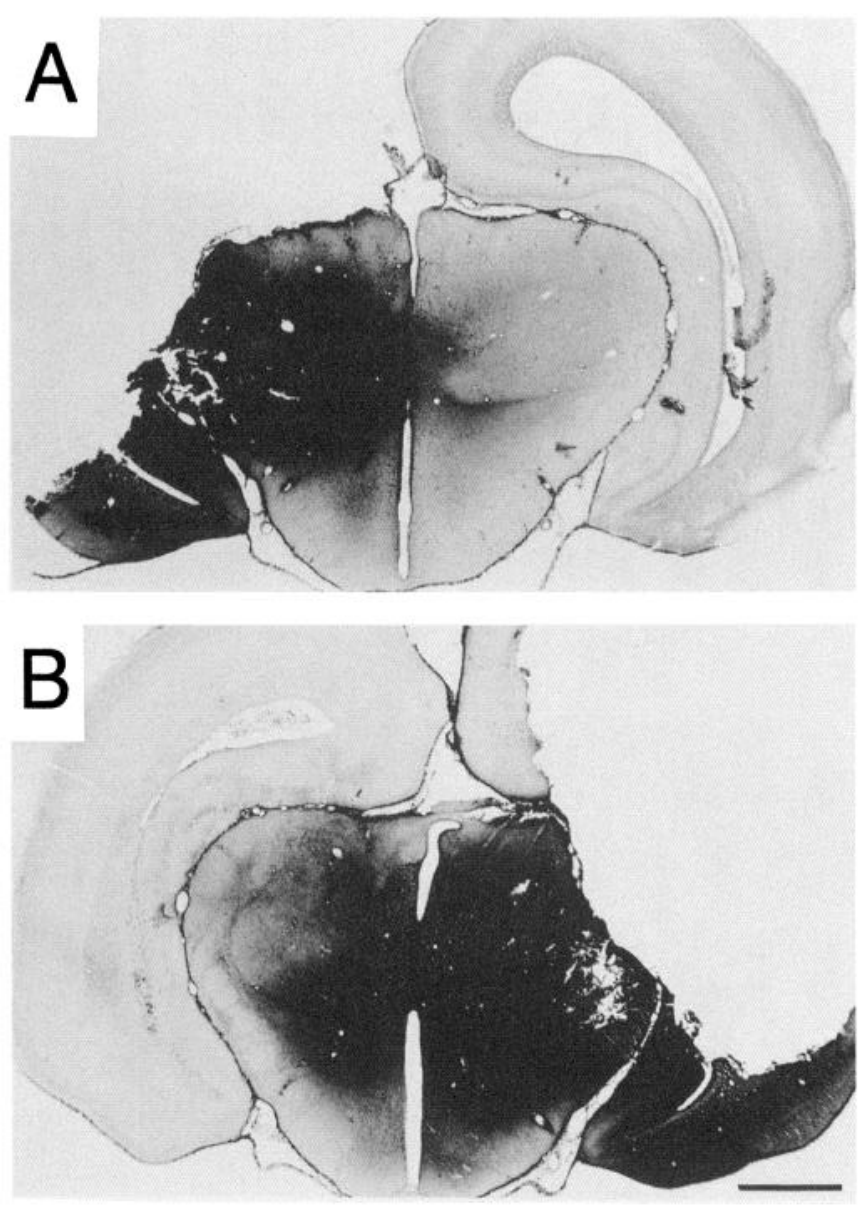

Figure 2. Transverse sections of the brain taken from a normally pigmented newborn ferret $(A)$ and an albino newborn ferret with one eye removed at E28 $(B)$. These animals had one side of the diencephalon labeled by neuronal tracers (WGA-HRP and HRP). The figures show the brains that had the least $(A)$ and the most $(B)$ spread of label. One side of the brain is heavily labeled, including the optic tract and the lateral geniculate nuclei. The label in $(A)$ is limited to one side, but in $B$ it spreads across the midline of the brain. However, it is evident that the lateral parts of the thalamus and the overlying visual cortex opposite to the implanted side are free of any label, indicating that major retinal recipient nuclei were not labeled (see Results). Dorsal is up. Scale bar, $1 \mathrm{~mm}$.

contralateral retina and a well-defined ventrotemporal ipsilateral crescent. The retrogradely labeled retinal ganglion cells on the side of the tract injection are shown in Figure $3 A$ for a neonatal rat and in Figure $3 B$ for an adult rat. In the adult the individual cell bodies and their proximal dendrites are distinctly revealed by the reaction product, and the different cell classes can be distinguished on the basis of size. In the newborn the dendrites are not as well shown as in the adult and the size classes are not yet distinguishable in our preparations. Although the labeling of some cells is relatively light in newborn animals, the outlines of individual cells can be readily recognized even when they are lightly stained. Also the dendrites of these cells are sufficiently clear to allow one to recognize the nerve cells as distinct from blood cells, which also contain reaction product.

In all the rats that have been studied, labeled cells were found throughout the ipsilateral retina. Most were in the ventrotemporal crescent but a number were sparsely but evenly distributed across the rest of the retina. The nasal border of the temporal

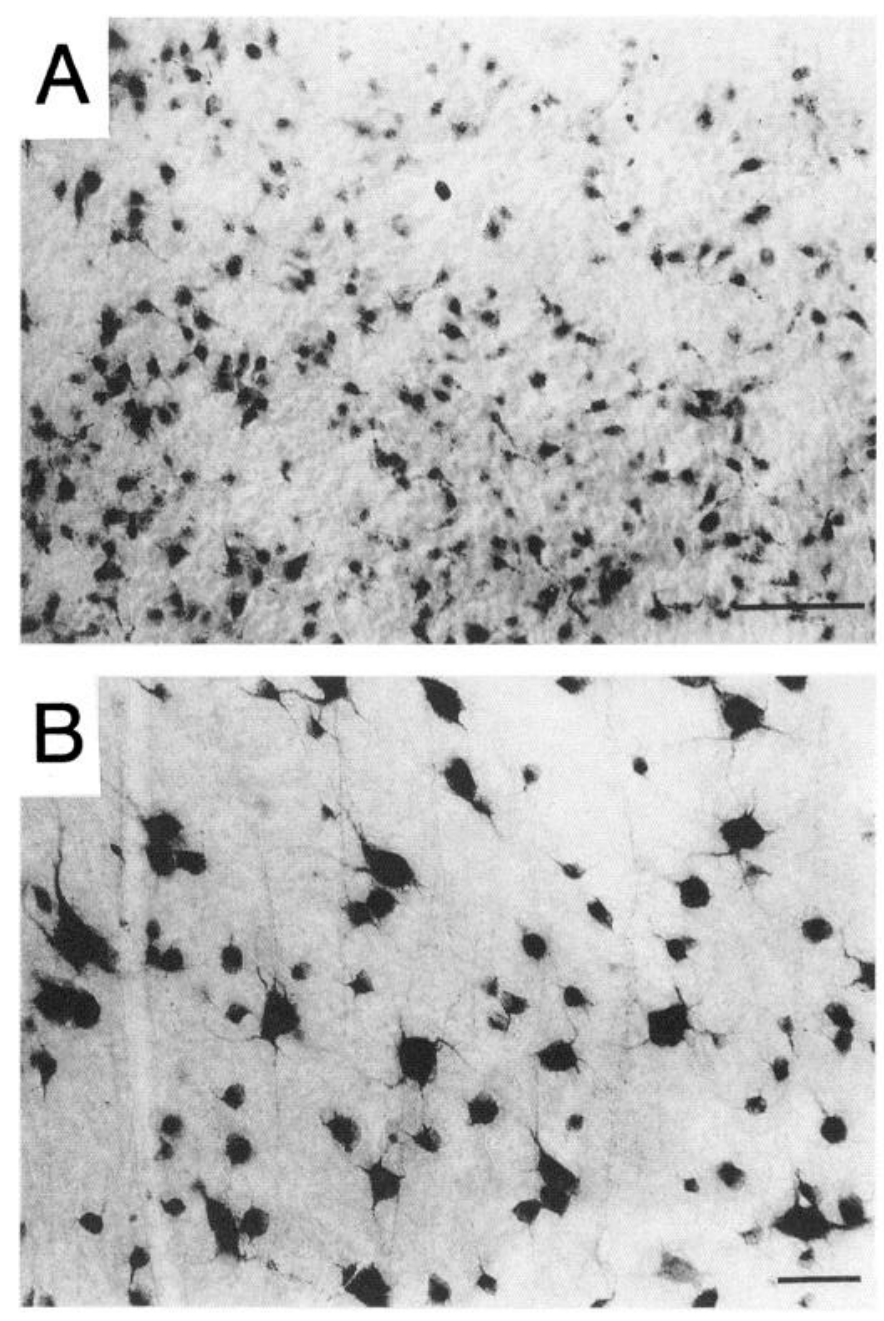

Figure 3. Micrographs to show the quality of labeling obtained for ipsilaterally projecting ganglion cells after injections of WGA-HRP into the region of the optic tract (see Fig. 1). A, Cells from the temporal retina of a normal, newborn pigmented rat. $B$, Cells from the temporal retina of an adult pigmented rat subjected to a prenatal monocular enucleation at E16.5. Scale bars, $50 \mu \mathrm{m}$.

retina is well defined in all retinas and is considered in more detail below.

\section{The effects of a prenatal enucleation on the adult uncrossed pathway in rats}

The prenatal enucleations were done at a stage (E16.5) when the first retinofugal fibers have passed the optic chiasm but none or only a few have yet invaded their terminal nuclei (Bunt et al., 1983; our own observations of anterograde transport of DiI; Chan, 1991). The effects of the prenatal enucleations on the uncrossed pathway of the adult are shown in Table 1 and Figure 4. The figures for the normal adults confirm that the uncrossed component is abnormally small in albinos relative to the normally pigmented animals. This applies to the temporal retina and to the nasal retina $(U=0 ; p<0.01$ for both).

In the pigmented rats, the early enucleation produces a slight increase in the total number of ipsilaterally projecting ganglion cells (from a mean of $2502 \pm 124$ to $3156 \pm 357$; but this is not significant: $U=2, p>0.05$ ). This increase is entirely due to a large and significant increase in the nasal retina (from 256 


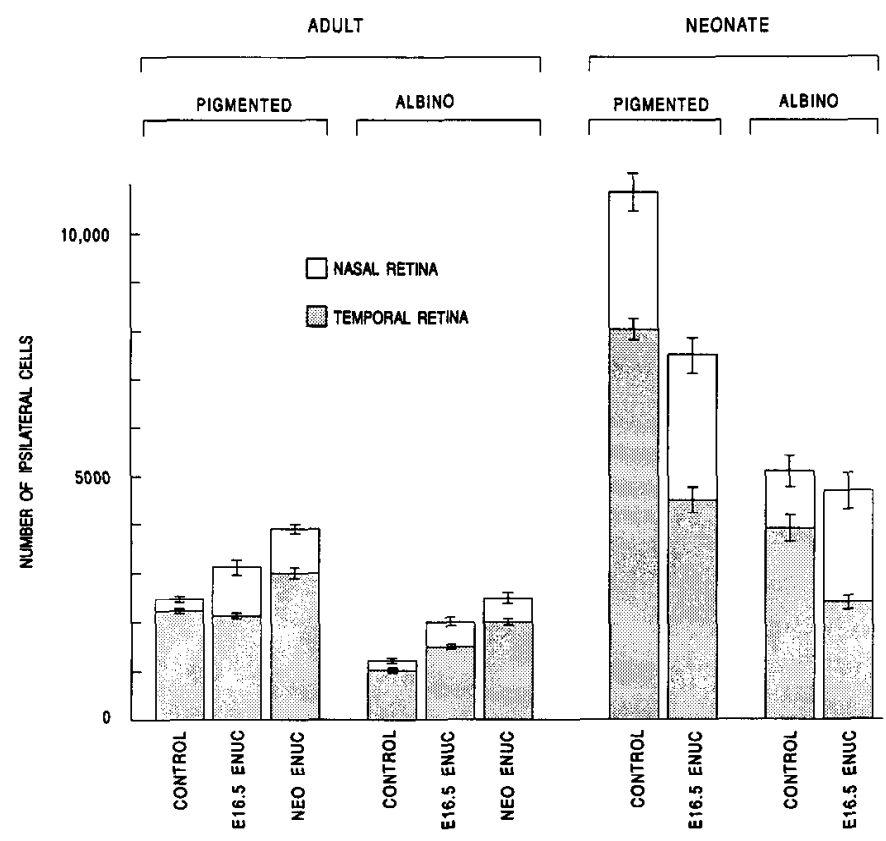

Figure 4. Bar diagram to show the numbers of ipsilaterally projecting ganglion cells in the nasal and temporal parts the retina in normal and experimental rats. The results seen in adults after prenatal (E16.5) and neonatal enucleations in normally pigmented and albino rats are shown on the left for comparison with the results seen at birth after prenatal enucleations, on the right.

\pm 34 to $950 \pm 185: U=0 ; p<0.001)$. The temporal retina shows no significant change ( $2246 \pm 105$ to $2196 \pm 174)$.

In the albino animals there is a significant increase in the total size of the uncrossed component (from $1228 \pm 70$ to $1973 \pm$ 180: $U=0 ; p<0.001$ ), and in these animals both nasal and temporal retina contribute to the increase, but again, whereas the former is statistically significant (from $179 \pm 6$ to $529 \pm$ 63: $U=0 ; p<0.001$ ), the latter is not (from $1049 \pm 76$ to $1444 \pm 126: U=1 ; p>0.05$ ).

Overall, there is an increase in the uncrossed pathway, which is stronger for nasal than for temporal retina and which can be seen in normally pigmented and albino animals, possibly being somewhat greater in albinos. The decrease expected from earlier studies in mice and ferrets (Godement et al., 1987a; Guillery, 1989) has not been found, nor is there any support for the view that the early enucleation is less effective in albino than in normal animals.

Two factors may have contributed to this result. One is that an earlier enucleation, done before any fibers had reached the chiasm, might have produced a different result, more like that seen in mice and ferrets. Unfortunately, we have not been successful in obtaining any survivors from earlier enucleations, and so have been unable to check this point. Another factor is that we may be dealing with two separate and opposite actions of enucleation, and the balance between these actions needs to be defined. On the one hand there may be a reduction of the uncrossed pathway produced by an early enucleation such as that previously demonstrated in mice and ferrets (Godement et al., 1987a; Guillery, 1989), and on the other is the increase in the uncrossed pathway that occurs during postnatal development when one retinofugal pathway develops in the absence of any interactions with the other (see Jeffery and Perry, 1982; Jeffery, 1984; Linden and Sefarty, 1985; Chan and Jen, 1988). This
Table 1. Numbers of ipsilaterally projecting ganglion cells in adult rats that have received a monocular enucleation either at E16.5 or on the day of birth

\begin{tabular}{|c|c|c|c|}
\hline \multirow[b]{2}{*}{ Animals } & \multirow{2}{*}{$\begin{array}{l}\text { Number } \\
\text { of animals } \\
\text { in sample }\end{array}$} & \multicolumn{2}{|c|}{$\begin{array}{l}\text { Number of ipsilaterally projecting } \\
\text { ganglion cells } \pm \text { SEM }\end{array}$} \\
\hline & & $\begin{array}{l}\text { Temporal } \\
\text { crescent }\end{array}$ & Total \\
\hline $\begin{array}{l}\text { Pigmented } \\
\text { controls }\end{array}$ & 4 & $2246 \pm 104.6$ & $2502 \pm 124.2$ \\
\hline $\begin{array}{l}\text { E16.5 pigmented } \\
\text { enucleates }\end{array}$ & 3 & $2196 \pm 174.5$ & $3156 \pm 357.4$ \\
\hline $\begin{array}{l}\text { Neonatal pigmer } \\
\text { enucleates }\end{array}$ & 3 & $2966 \pm 206.7$ & $3874 \pm 196.5$ \\
\hline Albino controls & 3 & $1049 \pm 76.4$ & $1228 \pm 70.3$ \\
\hline $\begin{array}{c}\text { E16.5 albino } \\
\text { enucleates }\end{array}$ & 4 & $1444 \pm 126.1$ & $1973 \pm 180.1$ \\
\hline $\begin{array}{l}\text { Neonatal albino } \\
\text { enucleates }\end{array}$ & 4 & $1891 \pm 143.8$ & $2613 \pm 219.4$ \\
\hline
\end{tabular}

second increase has, in general, been greater than that shown in Tablc 1 for the cumulative effect of pre- and postnatal development, suggesting that our results may show a prenatal decrease but that this is combined with a postnatal increase in the uncrossed pathway.

In order to separate the pre- and postnatal effects, we have looked at the effects of an early (E16.5) enucleation upon the uncrossed pathway that is developed at the time of birth and at the effects of a neonatal enucleation upon the pathway developed in the adult. The results for the normal and the albino rats are shown in Table 2 and Figure 4.

\section{The effects of a neonatal enucleation on the adult uncrossed pathway in rats}

The rats enucleated at birth and studied as adults show significant increases in the total uncrossed component for normal and also for albino animals, as expected from earlier such studies of rats (see references abovc). Both nasal and temporal parts of the uncrossed pathway are increased by a neonatal enucleation in both strains $(U=0 ; p<0.001$ for all comparable pairs in the same strain of rat). The increase for the total pathway above

Table 2. Numbers of ipsilaterally projecting ganglion cells in newborn rats that have received a monocular enucleation at E16.5

\begin{tabular}{|c|c|c|c|}
\hline \multirow[b]{2}{*}{ Animals } & \multirow{2}{*}{$\begin{array}{l}\text { Number } \\
\text { of animals } \\
\text { in sample }\end{array}$} & \multicolumn{2}{|c|}{$\begin{array}{l}\text { Number of ipsilaterally projecting } \\
\text { ganglion cells } \pm \text { SEM }\end{array}$} \\
\hline & & $\begin{array}{l}\text { Temporal } \\
\text { crescent }\end{array}$ & Total \\
\hline Pigmented & & & \\
\hline controls & 3 & $7912 \pm 445.9$ & $10,730 \pm 752.0$ \\
\hline $\begin{array}{l}\text { E16.5 pigmented } \\
\text { enucleates }\end{array}$ & 3 & $4488 \pm 553.7$ & $7406 \pm 655.7$ \\
\hline Albino controls & 3 & $3882 \pm 429.6$ & $5149 \pm 512.5$ \\
\hline $\begin{array}{c}\text { E16.5 albino } \\
\text { enucleates }\end{array}$ & 3 & $2339 \pm 300.5$ & $4702 \pm 703.1$ \\
\hline
\end{tabular}


Figure 5. Diagrams to show the distribution of labeled ganglion cells in the retina of newborn rats ipsilateral to the injected tract. Each dot represents the counts within an area of $300 \times 300 \mu \mathrm{m}^{2}$ (see Materials and Methods). $A$ was taken from a normally pigmented rat, and $B$ was from an albino. The figure shows that the albino has fewer ipsilaterally projecting cells in the temporal and also in the nasal retina than does the normally pigmented animal. Further, the nasal border of the temporal retina, marked by an obliquely running line, is farther toward the temporal margin in the albino retina. $A$ straight line was extended from the optic disk to the temporal periphery and the density plots of Figure 6 were taken from readings on this line (see Materials and Methods). Dorsal is up, temporal to the left. Scale bar, $1 \mathrm{~mm}$.
A

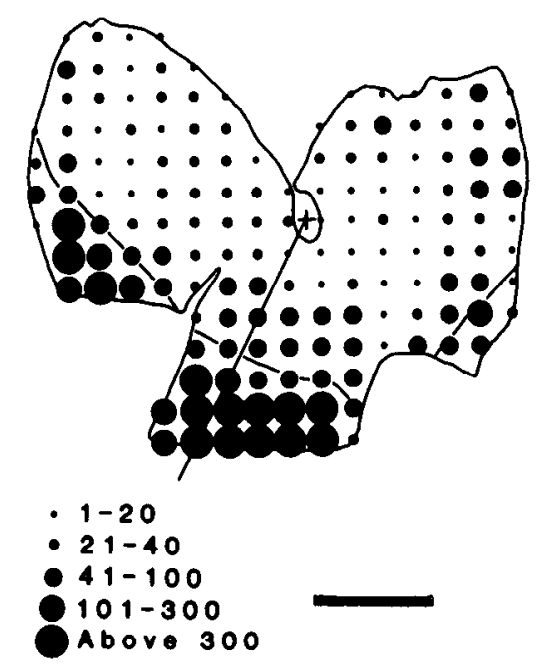

B

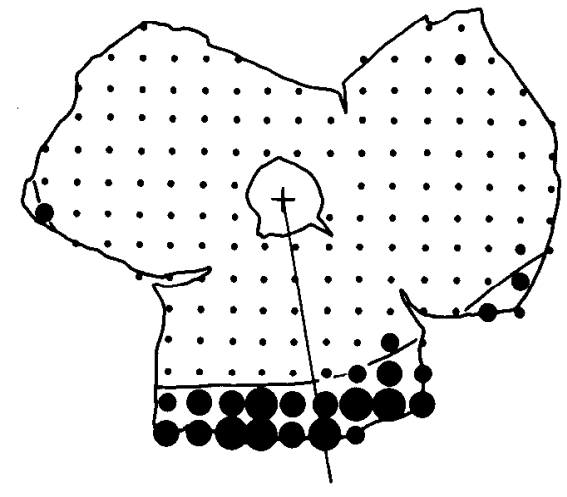

the normal control values is about the same for normal and albino animals, and this therefore represents a higher percentage increase for the albinos. In both strains of rat the increases are numerically greater for the temporal retina but represent a greater percentage increase for the nasal retina. The increases produced by neonatal enucleations are greater than those produced by prenatal enucleations, the differences being more marked for temporal than for nasal retinas. These differences confirm the suggestion that the prenatal and the postnatal modifications of a monocular pathway may tend to produce opposing results.

\section{The effects of a prenatal (E16.5) enucleation on the neonatal uncrossed pathway in rats}

The control animals for this series of experiments show that albino rats have an abnormally low number of ipsilaterally projecting ganglion cells even at this early stage (Fig. 4), confirming previous observations of the early development of the albino abnormality in other species (Shatz and Kliot, 1982; Cucchiaro and Guillery, 1984; Morgan and Thompson, 1985; Cucchiaro, 1991). The difference between albinos and normals is significant for the temporal crescent and for the nasal retina $(U=0 ; p<$ 0.001 for each), both values being only about $50 \%$ of normal for the albinos.

Animals enucleated prenatally and studied as newborns (Table 2) show a reduction in the total number of ipsilaterally projecting ganglion cells relative to controls for both strains of rat. However, whereas the reduction is about $30 \%$ for the pigmented animals and statistically significant $(U=0 ; p<0.001)$, it is only $9 \%$ for the albinos and not significant $(U=4 ; p>$ $0.05)$.

These results for the total pathway could be seen as confirming the previous suggestion, based on the retinogeniculate pathway of ferrets (Guillery, 1989), that an early enucleation affects normally pigmented animals but does not affect albinos. However, a glance at Figure 4 and an analysis of the changes produced in the nasal as opposed to the temporal retina suggest a different conclusion. The early enucleation has had a significant effect on the number of ipsilaterally projecting ganglion cells in the temporal retina of both strains, producing a significant reduction here $(U=0 ; p<0.001)$, but it has also produced an increase in the number of these cells in the nasal retina of albinos relative to a binocular albino pup $(U=0 ; p<0.001)$.

We conclude that the early enucleation does produce a reduction in the number of ipsilaterally projecting ganglion cells developed in the temporal retina prenatally, and that this effect is present in albino as well as in normal animals. Further, it appears that the prenatal changes produced by the early enucleation are obscured, and to a significant extent reversed by changes that occur postnatally when one retinofugal pathway develops in the absence of the other.

\section{The action of an early enucleation on the nasal border of the temporal retina in rats}

Although the change from the relatively high density of ipsilaterally projecting ganglion cells in the temporal retina to the lower values in the nasal retina is not sharp, it has not been difficult to define the border of the temporal retina visually (see Materials and Methods and Fig. 5), and when the control pigmented newborn animals were compared with the control albino newborn animals it was clear that in albinos the border was further lateral than in normals. Similar observations were obtained in retinas of adult rats (not shown), which show that there is a lateral shift in the nasal border of the temporal retina in albinos, in accord with expectations from other adult species (Stone et al., 1978; Cooper and Pettigrew, 1979; Dräger and Olsen, 1980; Morgan et al., 1987). The abnormal position of this border is therefore characteristic for albinos, and if the early enucleation in a pigmented animal had tended to produce a reduction of the uncrossed pathway that resembled the reduction in albinos then one would expect to find that the border had been shifted toward the temporal periphery.

Drawing the border by visual inspection suggested that the enucleation had not shifted the position of the border at all. In order to look at this possibility more closely, the nasal border of the temporal retina in newborn rats was defined by plotting cell densities from the optic disk to the temporal periphery (see Materials and Methods) for each of the control and experimental animals as shown in Figure 6. The top part of the figure shows the difference between the albino and normally pigmented animals in the position of the nasal border of the temporal retina, which is nearer to the temporal margin in the albinos. The 


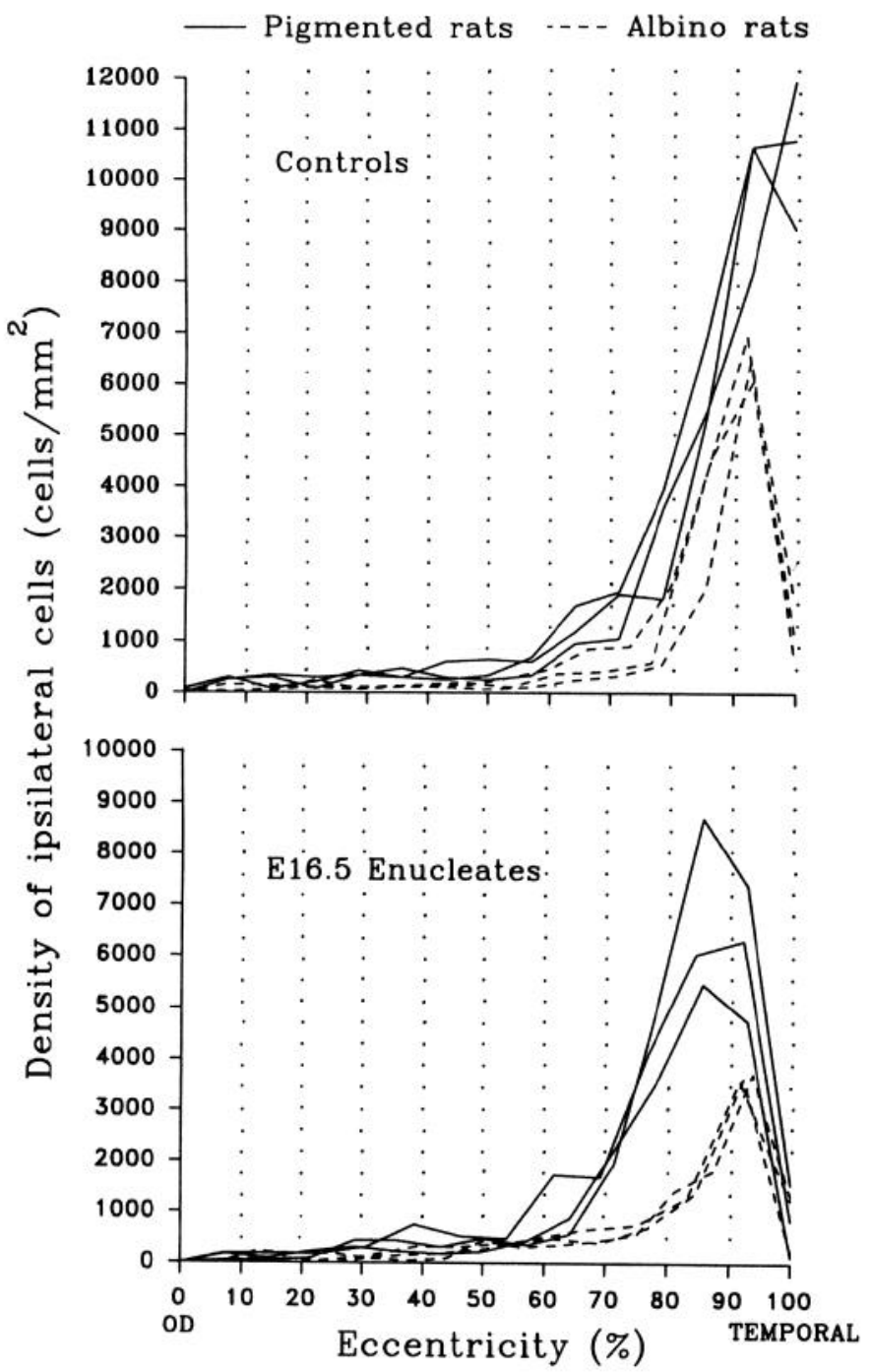

Figure 6. Plots from the experimental rats to show the densities of ipsilaterally projecting retinal ganglion cells at points extending from the optic disk $(O D)$ to the temporal periphery (TEMPORAL) (see Materials and Methods and Fig. 5). The major difference between the normally pigmented and the albino animals is in the position of the border of the high densities of the ipsilaterally projecting ganglion cells in the temporal retina. This is not affected by the prenatal enucleations even though these enucleations reduce the numbers of ipsilaterally projecting ganglion cells (see Results).

bottom part of this figure shows that this difference is preserved in the enucleated animals with essentially no change. The early enucleation has no effect on the nasal border of the temporal retina; it reduces the number of ipsilaterally projecting ganglion cells, thus reducing the density of these cells and altering the slope of lines drawn in Figure 6 , but the difference between normally pigmented and albino animals is maintained in spite of the effects of the early enucleation.

Figure 6 shows that for the normally pigmented animals, the early enucleation produces a major part of the loss of ipsilaterally projecting ganglion cells in the far temporal part of the retina. This suggests that the enucleation may have had its most severe effect on the cells generated last, as it has been shown in the rat retina that ganglion cells are generated in a rough central to peripheral order (Reese and Colello, 1992). Comparison of the normal albino and the normal pigmented animals shows that
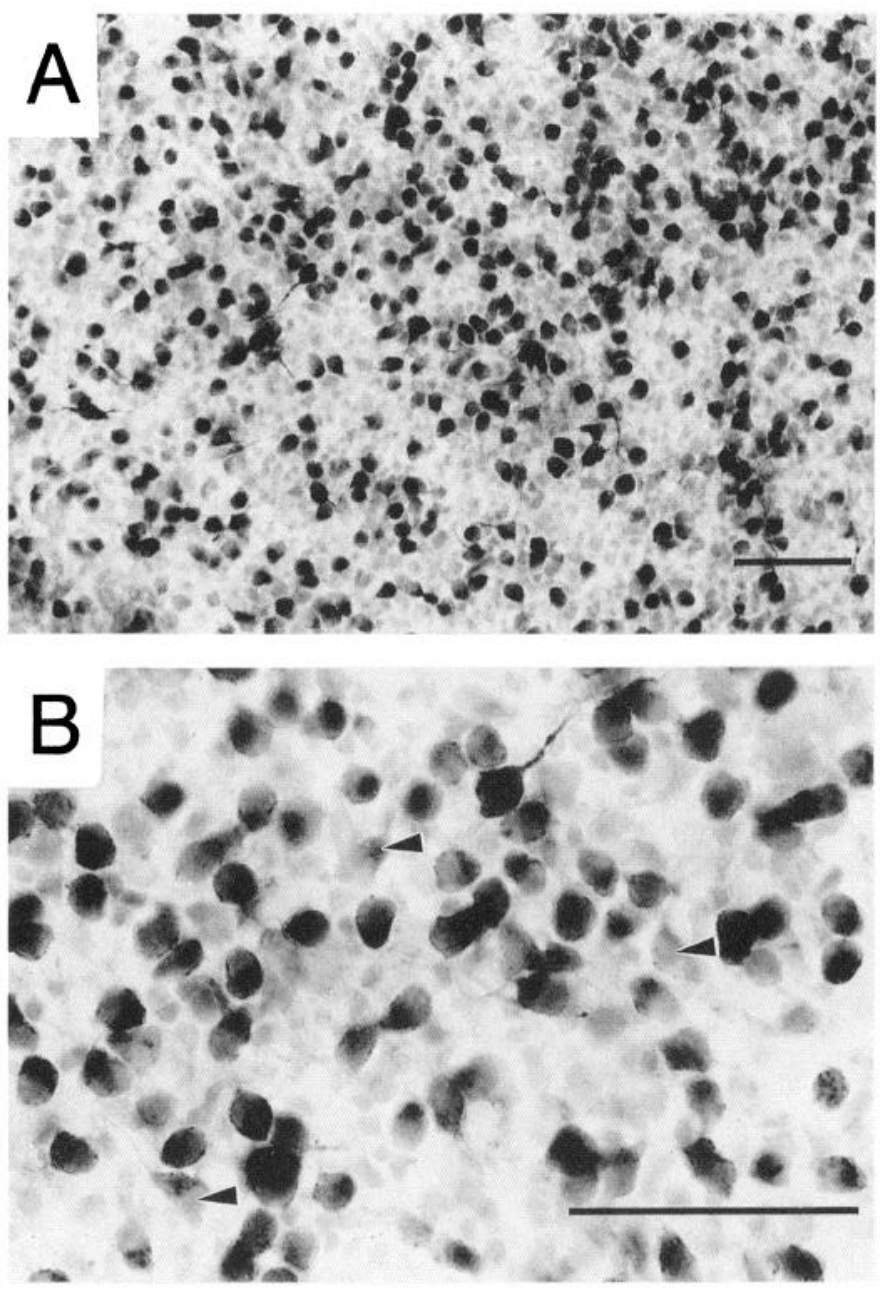

Figure 7. Light micrographs to show the quality of the retrograde labeling of ipsilaterally projecting retinal ganglion cells in the temporal retina of a normally pigmented newborn ferret produced by an injection of WGA-HRP into the region of the optic tract. At this age the labeled cells are relatively uniform in size and some of them have their dendrites labeled $(A)$. Most of these cells were darkly labeled but some of them only had light label. These lightly labeled cells can be identified readily under an oil immersion lens $(B)$, which shows that these cells have one or more processes as well as the reaction product in the cytoplasm. (arrowheads). Scale bars, $50 \mu \mathrm{m}$.

although the major albino abnormality is in the regions next to the nasal retina, there is also a reduction in the number of ipsilaterally projecting ganglion cells in the far temporal retina. This may, again, reflect some action of the albino gene on the late-born ganglion cells. That is, to some extent the enucleation and the albino gene produce similar effects in the far temporal retina. However, the data show that these actions are additive, since there is a further reduction in the albinos after an early enucleation.

\section{Experiments on ferrets}

Since in the rats the effects of the prenatal enucleations tended to be neutralized during the period of postnatal cell death, all of the ferrets were studied at birth.

\section{Labeling of the ipsilaterally projecting ganglion cells in ferrets}

In the control ferrets, 30 of the 34 normal animals that received a unilateral tract injection showed densely labeled cells throughout the contralateral retina, and a distinct labeled crescent in 

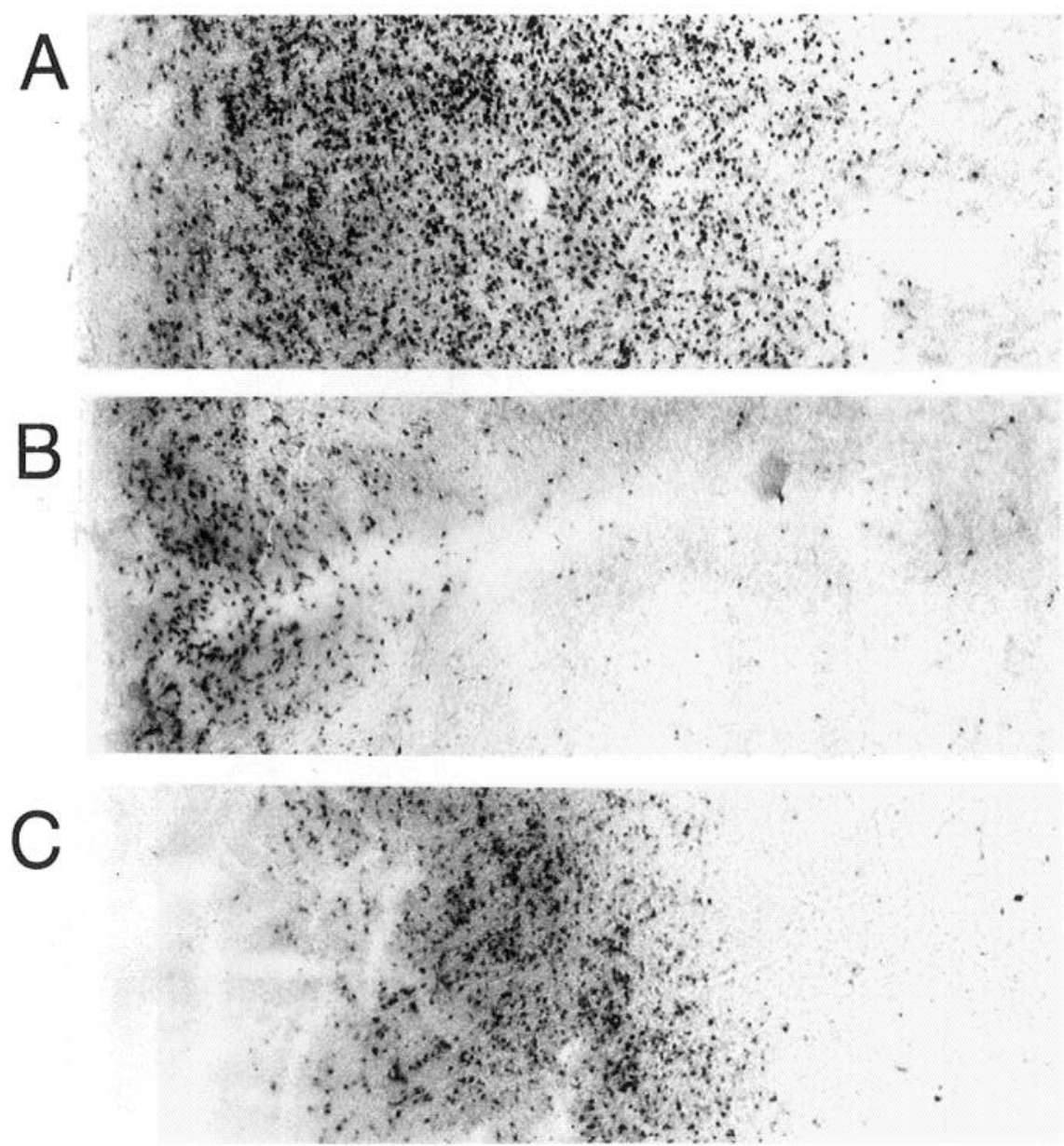

Figure 8. Light micrographs to show the retrogradely labeled ipsilaterally projecting ganglion cells in the temporal retina of newborn ferrets. The temporal retinal edges were aligned on the left. A was taken from a pigmented control, and $B$ was from an albino control; $C$ and $D$ illustrate the temporal concentration of labeled ipsilateral cells in a pigmented $(C)$ and an albino $(D)$ ferret after one eye had been removed at E28; $E$ shows the temporal retina from an albino ferret that had one eye removed at E28. Here the distinction between the temporal and nasal retina was lost. Scale bar, $200 \mu \mathrm{m}$.
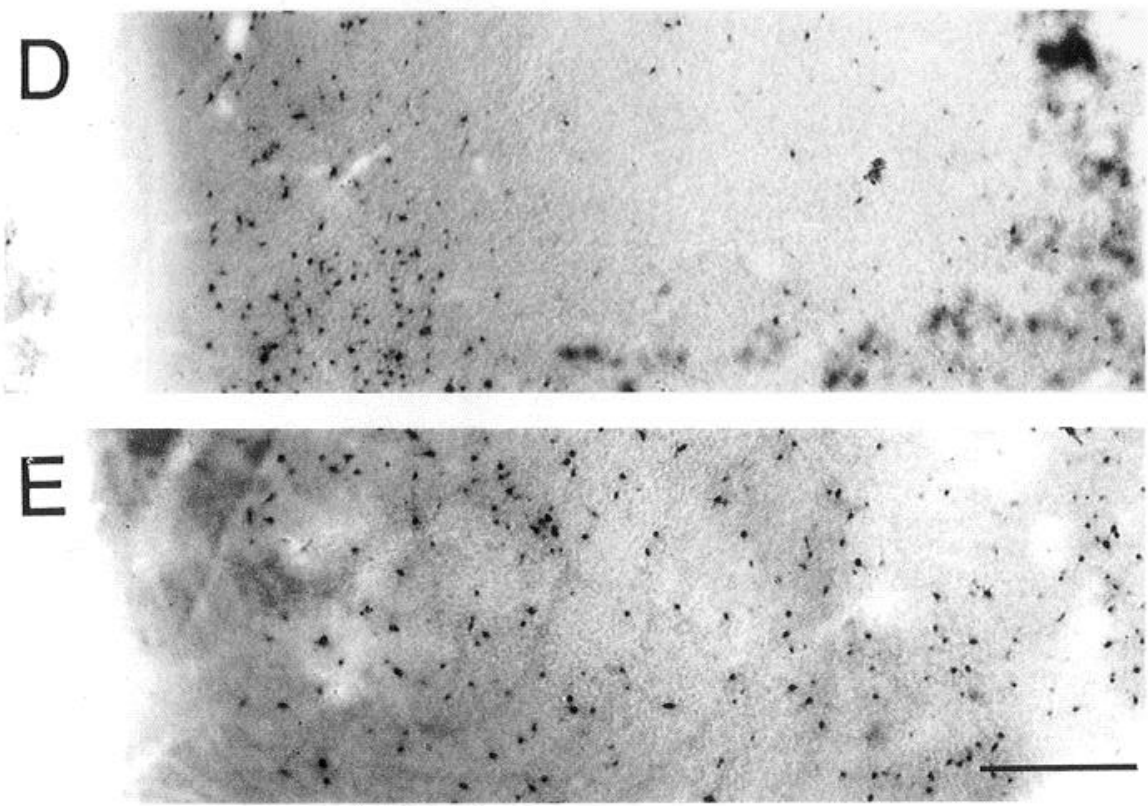

the ventrotemporal retina ipsilateral to the tract injection. Figure 7 shows the quality of the retrograde filling of retinal ganglion cells in the ipsilateral retina of the ferrets. The cells are mostly round and have a relatively uniform soma size (Fig. $7 A$ ). Some cells show one or two dendrites extending for short distances.
Most cells show a well-defined dense, dark brown reaction product, but in all of the retinas there are some cells that are only lightly labeled with fine granules of HRP. These are readily distinguished from unlabeled cells with an oil immersion objective (Fig. 7B). 


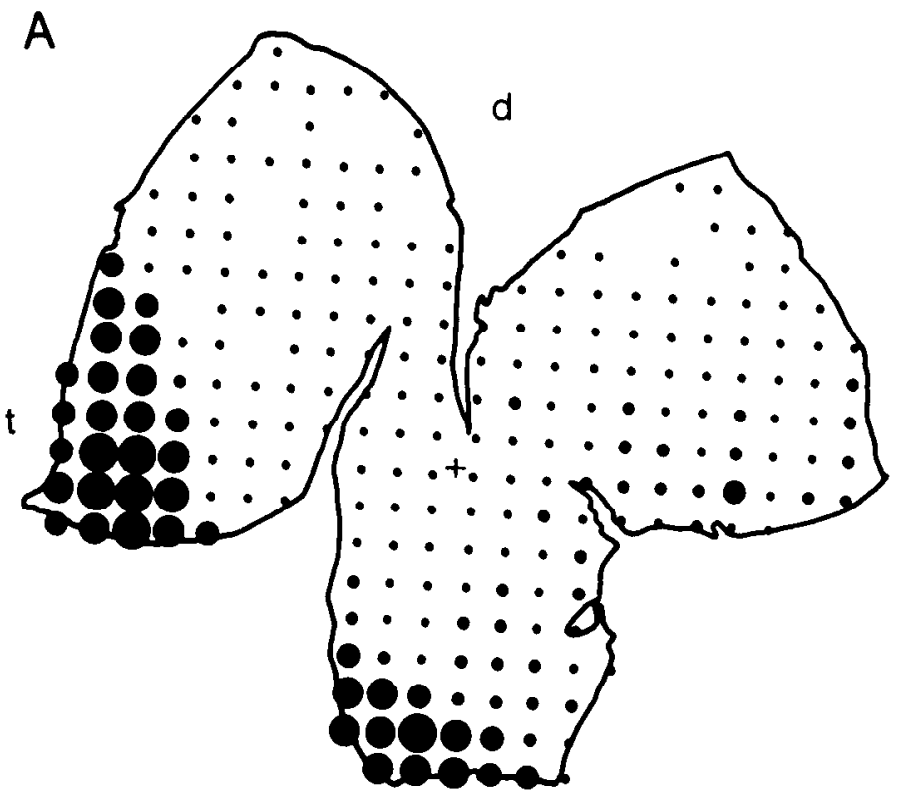

B

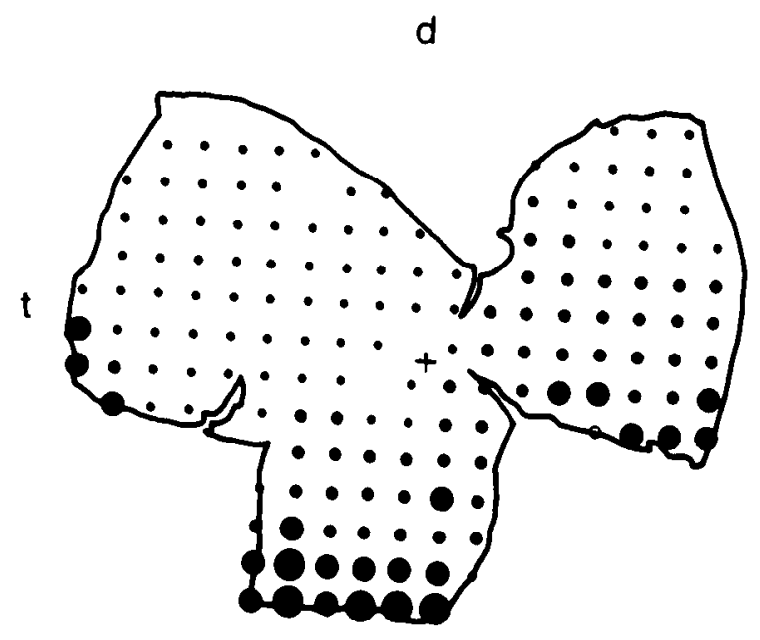

$1-20$
$-\quad 21-50$
$51-200$
$201-500$
Above 500

C
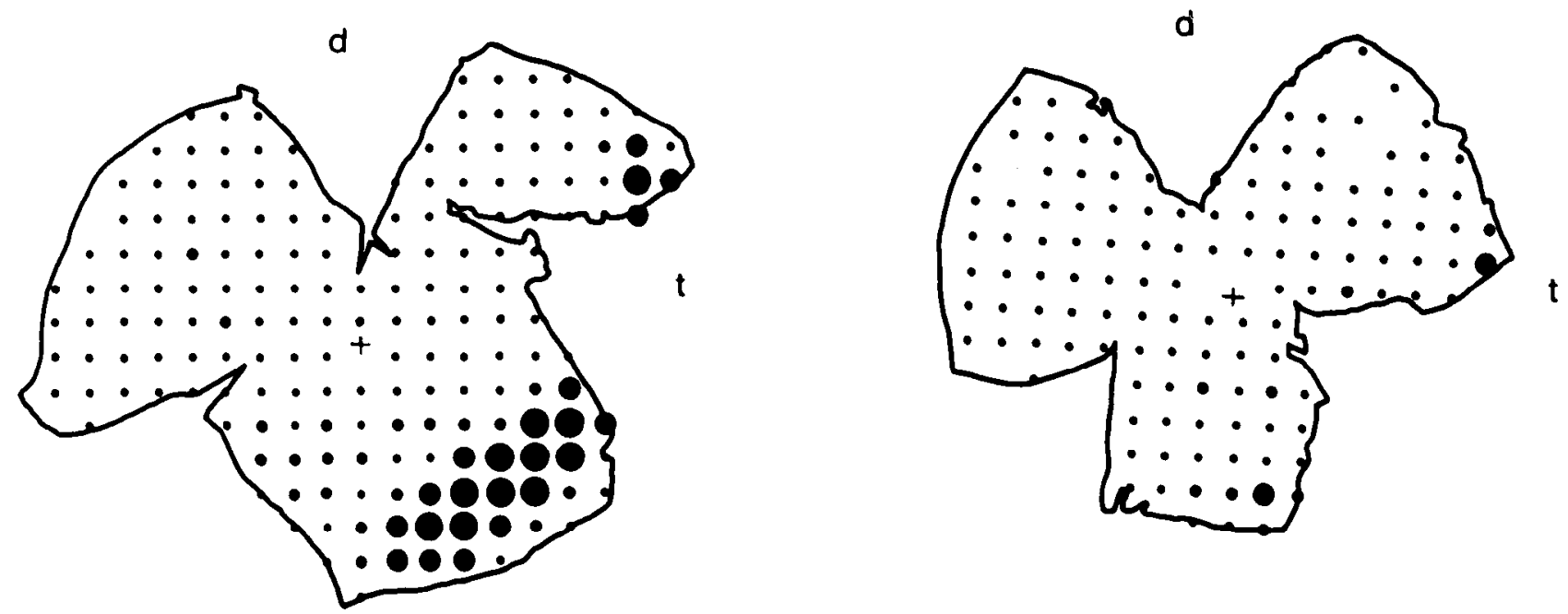

Figure 9. Dot diagrams to illustrate the distribution of ipsilaterally projecting ganglion cells in the retinas of newborn ferrets. $A$ is a pigmented control, $B$ is an albino control, $C$ is from a pigmented animal with one eye removed at E28, and $D$ is from an E28 albino enucleate. All these animals show a concentration of labeled ipsilateral cells in the temporal retina. $d$, dorsal; $t$, temporal; the optic disk is indicated by a small cross. Each dot indicates the number of labeled cells in an area of $300 \times 300 \mu \mathrm{m}^{2}$. Scale bar, $500 \mu \mathrm{m}$.

The numbers of ipsilaterally projecting ganglion cells in the retina of ferrets

Control animals. For all of the normal (control) animals in which the contralateral retina was completely labeled and for many of the experimental animals, it was possible to define the temporal retina as a ventrotemporal crescent that contained a dense population of ganglion cells and the nasal retina as a larger more lightly labeled region on the nasal side of this. Examples of the cell distributions are shown in Figure 8 in micrographs and in Figures 9 and 10 in diagrammatic summaries. Table 3 summarizes these results for all of the experimental and control animals.

The results show that at birth there is already a significant difference between normally pigmented and albino control animals, as would be expected from previous studies (Cucchiaro and Guillery, 1984; Morgan and Thompson, 1985; Cucchiaro, 1991). The total number of ipsilaterally projecting ganglion cells 
A

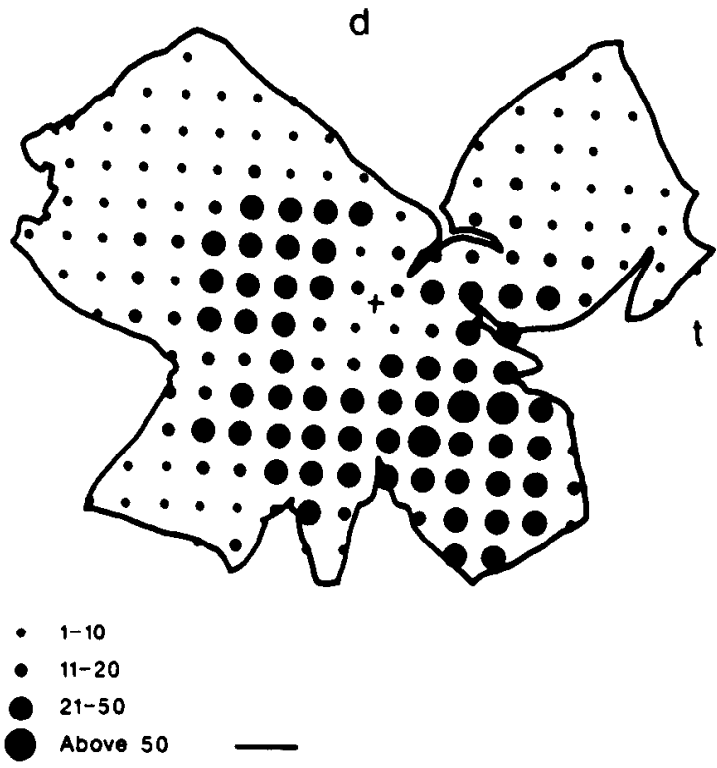

B

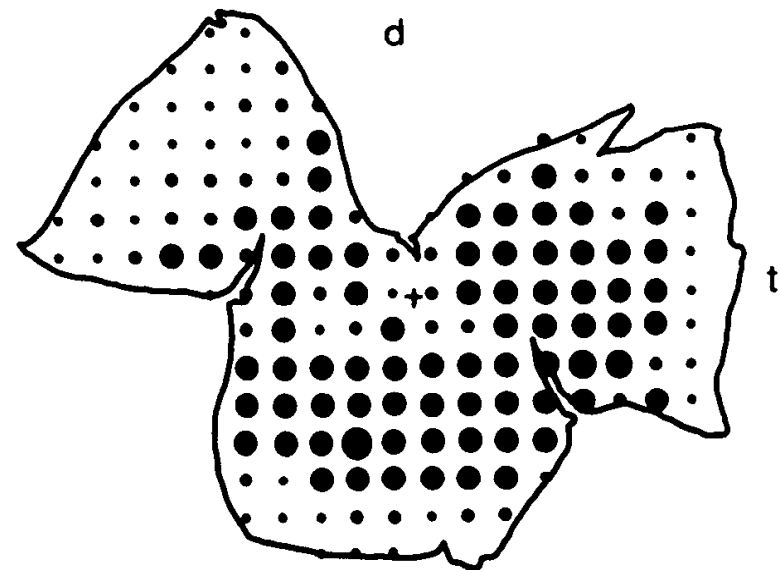

C
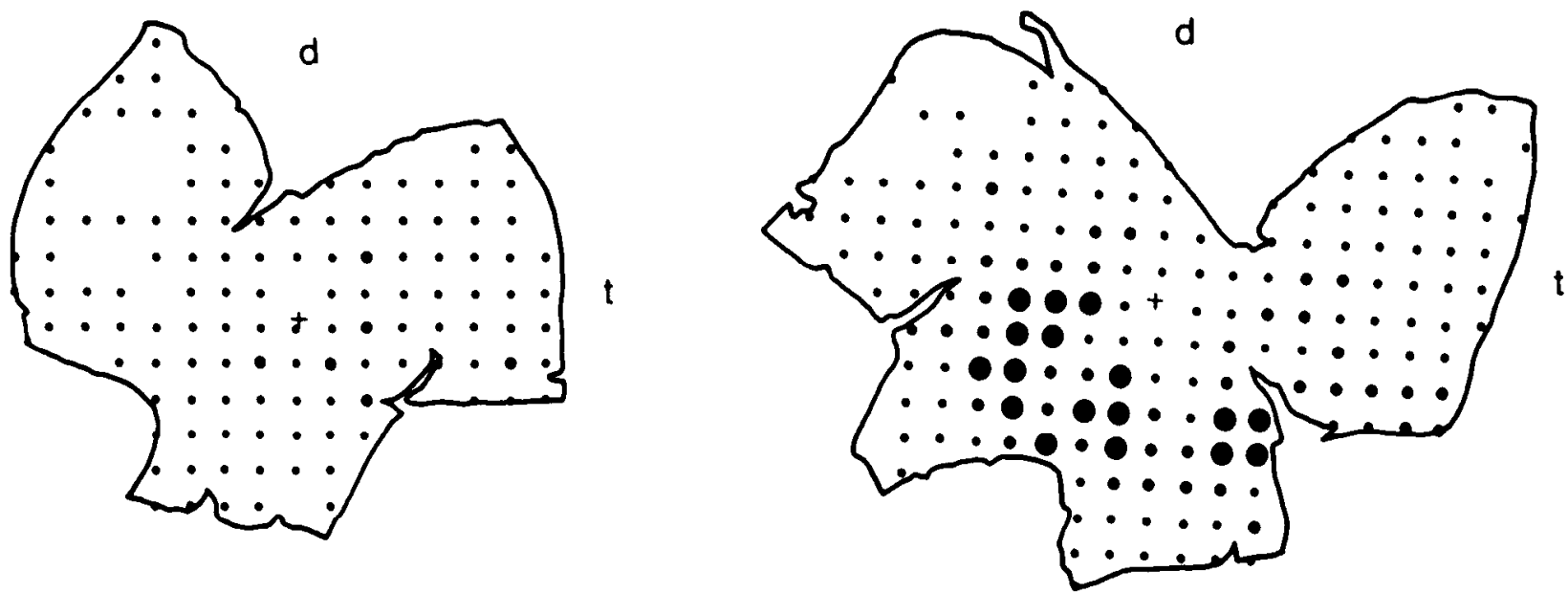

Figure 10. Dot diagrams to show the distribution of ipsilaterally projecting ganglion cells in the retinas of newborn ferrets. $A$ and $B$ are from two E28 albino enucleates, $C$ is from a pigmented ferret with one eye removed at E27, and $D$ is from an albino ferret with one eye removed at E27. In these animals there is no recognizable concentration of labeled ipsilateral cells in the temporal retina. Note the dot scale is much smaller than the one used in Figure 4. $d$, dorsal; $t$, temporal. The dots indicate the number of cells in an area of $300 \times 300 \mu \mathrm{m}^{2}$. Scale bar, $500 \mu \mathrm{m}$.

is greater in the normally pigmented than in the albino animals $(U=0 ; p<0.05)$. The difference is clearly seen in the temporal retina $(U=0 ; p<0.05)$ but is small and not significant for the nasal retina $(U=5.5)$.

E28 enucleations. When the enucleations were done at E28, a stage when retinofugal axons have reached the optic tract but have not yet entered the lateral geniculate nuclei (Cucchiaro and Guillery, 1984), the enucleations produced a marked reduction of the uncrossed component from the surviving eye in normally pigmented and in albino animals. The total reduction for the whole retina was significant for both color phases $(U=0 ; p<$ $0.05)$. In pigmented animals the numerical difference was significant for both parts of the retina, the nasal and the temporal $(U=0 ; p<0.05)$. For albino animals the temporal retina could not be identified at all in four of the six animals (Fig. 10A,B), and in the two that allowed the identification of a temporal retina the number of ipsilaterally projecting ganglion cells in the temporal retina was obviously reduced (Fig. 9D). This result is shown in Figure 11 by the subdivision of the bar for the E28 albinos into two parts, one part (1/3 of the bar width) representing the animals with a surviving temporal retina, and one part ( $2 / 3$ of the bar width) representing those with no temporal retina. For all six albino animals, the total number of ipsilaterally projecting ganglion cells was significantly reduced $(U=\mathrm{O}$; $p<0.05$ ).

When all E28 enucleations are considered together, it is clear that the enucleation produces a marked reduction in the surviving uncrossed pathway for albino and for normal animals, 
affecting both parts of the retina roughly equally in pigmented animals. In the albinos, where the temporal retina is initially small, the further reduction produced by the enucleation has led to a complete disappearance of the distinction between the nasal and the temporal retina in four of the six animals.

E27 and E26 enucleations. Earlier enucleations produced more marked changes in normally pigmented and also in albino animals. In normally pigmented animals, six of the seven enucleations done at E27 gave results that were slightly more severe but essentially the same as those done at E28, for both the temporal and nasal retina. However, one of these seven animals showed no temporal crescent at all and showed only 478 ipsilaterally projecting cells (Fig. $10 \mathrm{C}$ ). This animal has been represented as one-seventh of the bar width illustrated in Figure 11 for the E27 pigmented animals and since it is so different from the others in this group this result at first raised some question of interpretation. However, since animals enucleated at E26 showed other retinas with no temporal crescent and fewer than 700 ipsilaterally projecting ganglion cells, it appears that the earlier enucleations must be regarded as producing this extreme effect, and that the one E27 animal showing this effect was probably at an earlier stage of development than the others at the time of the enucleation.

In the albinos all four E27 enucleates showed no clear temporal crescent (Fig. 10D), and values for the total numbers of ipsilaterally projecting cells were significantly lower than those in the E28 animals $(U=1 ; p<0.05)$.

At E26 nine pigmented animals were enucleated. No albino animal was studied at this stage. Four of the nine animals showed no temporal crescent. Overall, these nine animals showed some further reduction in the total number of ipsilaterally projecting ganglion cells relative to the values obtained from the E28 and E27 animals. This reduction was not significant relative to the

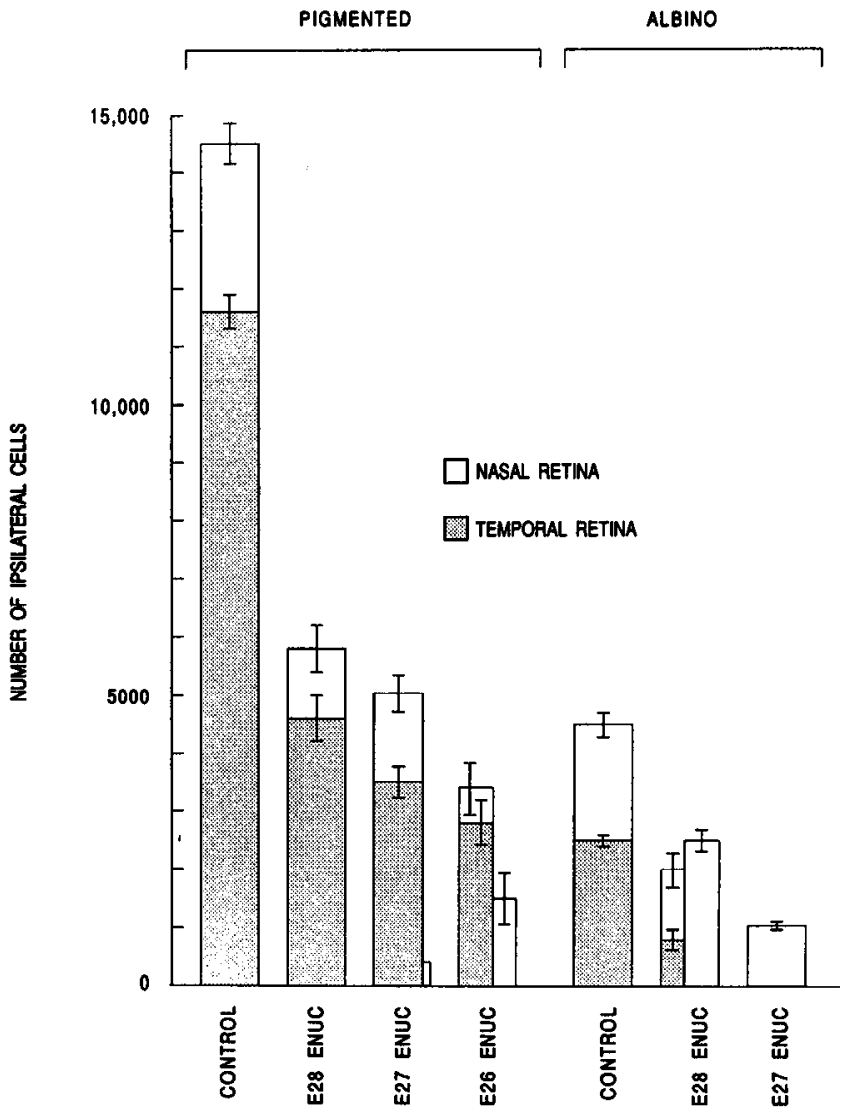

Figure 11. Bar diagram to show the number of ipsilaterally projecting retinal ganglion cells in control and experimental ferrets. The nasal and temporal sectors of the retina are shown separately. Further details in Results.

Table 3. Numbers of ipsilaterally projecting ganglion cells in newborn ferrets

\begin{tabular}{|c|c|c|c|}
\hline \multirow[b]{2}{*}{ Animals } & \multirow{2}{*}{$\begin{array}{l}\text { Number of } \\
\text { animals in } \\
\text { sample }\end{array}$} & \multicolumn{2}{|c|}{$\begin{array}{l}\text { Number of ipsilaterally projecting ganglion } \\
\text { cells } \pm \text { SEM }\end{array}$} \\
\hline & & Temporal crescent & Total \\
\hline $\begin{array}{l}\text { Pigmented } \\
\text { controls }\end{array}$ & 4 & $11,593 \pm 526.5$ & $14,416 \pm 731.1$ \\
\hline $\begin{array}{l}\text { E28 pigmented } \\
\text { enucleates }\end{array}$ & 6 & $4611 \pm 738.0$ & $5860 \pm 785.9$ \\
\hline $\begin{array}{l}\text { E27 pigmented } \\
\text { enucleates }\end{array}$ & $\begin{array}{l}6 \\
1\end{array}$ & $\begin{array}{c}3464 \pm 547.2 \\
\text { NTC }\end{array}$ & $\begin{array}{c}5188 \pm 625.7 \\
478\end{array}$ \\
\hline Summed values for all 7 animals & & $3464 \pm 547.2$ & $4455 \pm 848.0$ \\
\hline $\begin{array}{l}\text { E26 pigmented } \\
\text { enucleates }\end{array}$ & $\begin{array}{l}5 \\
4\end{array}$ & $\begin{array}{c}2544 \pm 742.6 \\
\text { NTC }\end{array}$ & $\begin{array}{l}3320 \pm 900.7 \\
1535 \pm 896.6\end{array}$ \\
\hline Summed values for all 9 animals & & $2544 \perp 742.6$ & $2529 \pm 677.9$ \\
\hline Albino controls & 4 & $2454 \pm 276.0$ & $4520 \pm 428.6$ \\
\hline $\begin{array}{l}\text { E28 albino } \\
\text { enucleates }\end{array}$ & $\begin{array}{l}2 \\
4\end{array}$ & $\begin{array}{l}734 \pm 340.0 \\
\text { NTC }\end{array}$ & $\begin{array}{l}1945 \pm 609.9 \\
2502 \pm 354.8\end{array}$ \\
\hline Summed values for all 6 animals & & $734 \pm 340.0$ & $2316 \pm 298.1$ \\
\hline $\begin{array}{l}\text { E27 albino } \\
\text { enucleates }\end{array}$ & 4 & NTC & $1092 \pm 197.4$ \\
\hline
\end{tabular}



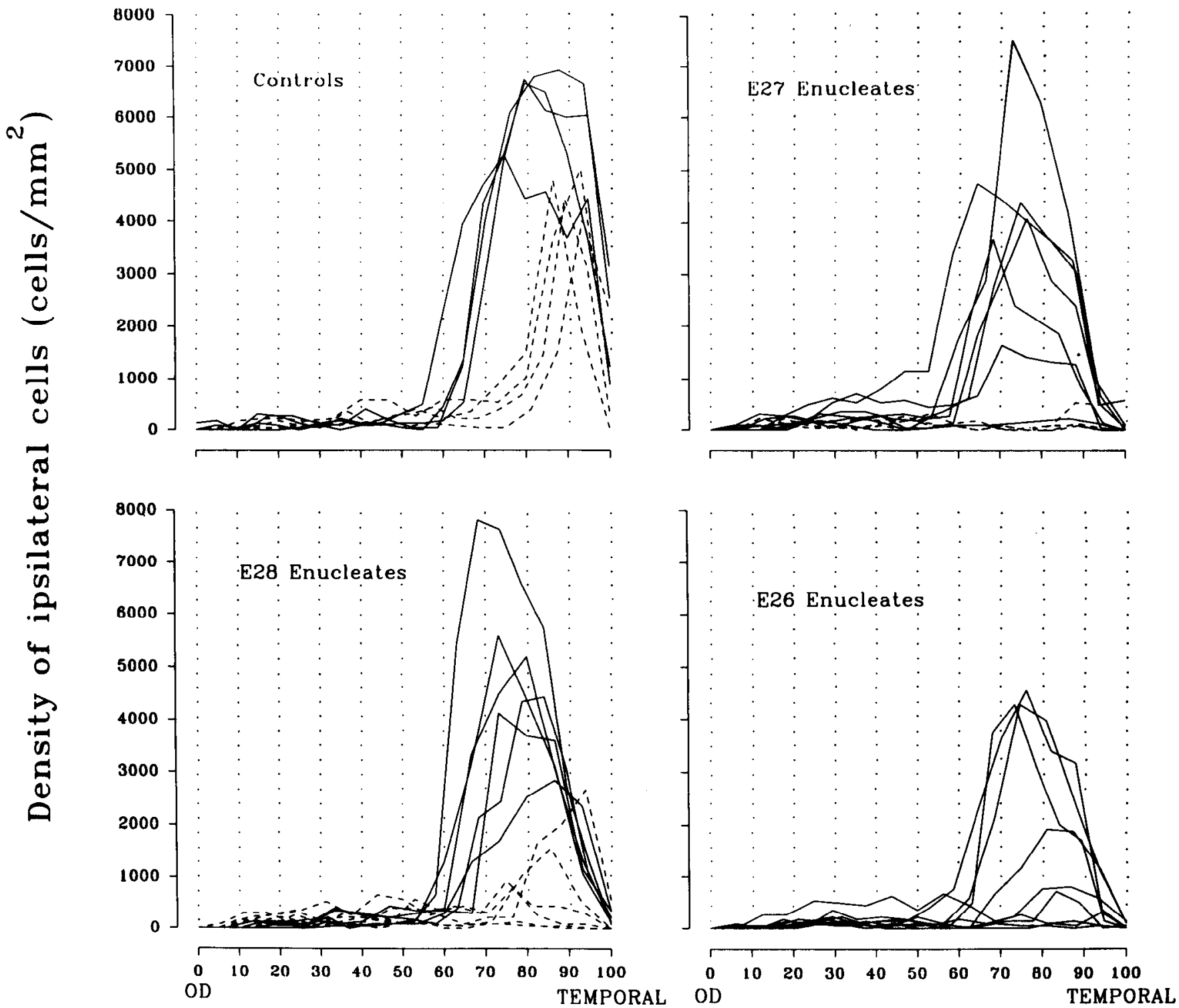

\section{Eccentricity (\%)}

Figure 12. Plots to show the relative densities of retrogradely labeled ipsilaterally projecting ganglion cells in newborn ferrets. The density of ganglion cells has been plotted starting from the optic disk $(O D)$ at the left and extending to the temporal margin of the retina $(T E M P O R A L)$ as in Figure 6. Distances are expressed as a percentage of the total distance between these two points.

E27 animals $(U=19 ; p>0.05)$, but was significant relative to the E28 animals $(U=6 ; p<0.05)$.

In summary, these experiments show that in both color phases of ferrets the early enucleation produces a reduction in the total number of ipsilaterally projecting ganglion cells. This reduction increases in severity progressively with earlier enucleations and leads to the elimination of the differentiated temporal crescent for earlier enucleations. Since the total number of ipsilaterally projecting ganglion cells is smaller for albinos than for normals and since the size of the temporal crescent is smaller in albinos, it is perhaps not surprising that for any onc agc at enucleation the number of ipsilaterally projecting ganglion cells is lower in albinos, and that the temporal crescent is lost in albinos by enucleations done at stages at which it is not lost in normally pigmented animals.

\section{The nasal border of the temporal retina in ferrets}

The density of ipsilaterally projecting ganglion cells has been plotted as for the rats, from the optic disk to the temporal periphery along a line perpendicular to the nasal border of the temporal retina, in each of the animals in which a differentiated temporal retina was identifiable. For those animals that did not have an identifiable temporal retina, readings of cell density were taken along a line stretching horizontally from the optic 
disk to the temporal margin of the retina. The results for normal and albino animals are presented in the four parts of Figure 12, in which control animals are compared with E28 enucleates on the left and E27 enucleates are compared with E26 enucleates on the right.

The left half of the figure shows that the E28 enucleation does not producc a shift in the nasal border of the temporal retina in either normal or albino animals although the loss of the temporal retina is clearly shown in two of the albino animals (see also Figs. 8, 10). It shows, further, that the enucleation does produce a reduction of ipsilaterally projecting ganglion cells in the most peripheral part of the temporal retina for normal animals. This is the same as the result seen in rats, and again suggests that the last-born cells may be most severely affected by the enucleation.

The right half of the figure shows the same loss of ganglion cells from the peripheral retina and also shows the complete loss of the temporal retina for the albinos after an E27 enucleation. Further, it is evident that the nasal border of the temporal retina is stable in pigmented animals at 55-65\% eccentricity until the temporal retina is almost completely lost in E26 enucleates, and then one sees in two of these animals that there is a modest rise in ganglion ccll density starting at $75-80 \%$ eccentricity, the value characteristic for albino animals. The two animals that showed this distribution both had very few (less than 900) cells in the temporal retina, which is far fewer than the number in the temporal retina of albino controls $(2454.3 \pm$ 276).

\section{Discussion}

General conclusions

The results we have obtained in rats and ferrets confirm earlier observations of mice and ferrets, that a monocular enucleation done prenatally at the time axons first reach the optic chiasm, or shortly thereafter, produces a reduction in the uncrossed pathway from the surviving cyc (Godement ct al., 1987a; Guillery, 1989). This is in marked contrast to an enucleation done at birth, which produces an increase in the uncrossed pathway. These different effects are discussed below. Our results demonstrate that the reduction of the uncrossed pathway occurs prenatally and is counteracted by the interactions occurring postnatally. Also, our results extend earlier studies in showing that the early enucleation produces some reduction of the uncrossed pathway even in albino animals, which start with an abnormally small one. In this they suggest that the albino mutation and the early enucleation produce their effects by different developmental mechanisms. This conclusion is confirmed by the demonstration that the enucleation does not affect the nasal border of the temporal retina: the clear difference between normal and albino animals in the position of this border survives the enucleation. It is probable that the albino gene acts in the eye whereas the enucleation acts at the chiasm.

\section{Differences between prenatal and postnatal enucleations (in rats)}

The postnatal enucleations confirm earlier reports that the surviving uncrossed component develops more than its normal number of ganglion cells in the adult (Jeffery and Perry, 1982; Jeffery, 1984; Linden and Sefarty, 1985; Chan and Jen, 1988; Chan et al., 1989). This relative increase appears to be due to a decrease in the normal cell losses affecting the uncrossed component. The cause of the normally occurring cell death is not clear, although the phenomenon has been extensively studied. To some extent it may well be due to the availability of only limited amounts of growth factors or synaptic surfaces at the terminal sites, but it is highly probable that other factors play a part, since even the rather extensive partial deafferentation produced in the contralateral terminal relays by a monocular enucleation saves only a relatively small proportion of cells in the surviving uncrossed pathway that would have died during normal development (see Jeffery, 1984; Chan et al., 1989; Fig. 4).

It is clear that a prenatal enucleation can produce a very substantial reduction in the uncrossed pathway developed by the surviving eye. This change has been seen clearly in rats, not only by studying the system at birth, but also by comparing the effects of a neonatal enucleation with those of a prenatal enucleation (see Fig. 4, Table 1). Possibly, enucleations done earlier than E16.5 in rats would have produced more marked effects. This remains an open question. The observations made by Godement et al. (1987a) in mice show that the reduction is greater if done earlier, as do our observations on ferrets. The contrary report by Sretavan and Reichardt (1993) appeared after this manuscript had been submitted. Their claim, that there is no change in the uncrossed pathway of mice after very early monocular enucleations, is puzzling in the light of earlier results and of the observations reported here.

In general the experiments demonstrate that different sets of developmental mechanisms are modified by the prenatal and the postnatal enucleations, the early enucleations producing a result that is the opposite of the result produced by the later enucleations. The mechanisms that may be acting prenatally are discussed below. Here we note that when the effect of the prenatal enucleation is complete, presumably shortly before birth, after most of the retinofugal fibers have passed the chiasm, the postnatal developmental sequence that characterizes one retinofugal pathway developing in the absence of the other, will be played through. That is, even though the prenatal enucleation produces a reduction of the number of uncrossed fibers that initially enter the tract, postnatal cell losses will subsequently be less than during normal, binocular development, so that the best time to see the fullest effects of the prenatal enucleation is before the period of cell death, that is, shortly after birth in rats and ferrets.

The opposing effects seen pre- and postnatally are important because they raise the possibility that the prenatal effect will appear to be weaker than it really is, and may even appear to be absent if the pathways are studied after the period of maximum cell death. Studies of early enucleations done in marsupials (Mendez-Otero et al., 1986; Coleman and Beazley, 1989) and in cats (Sretavan and Shatz, 1986) showed no or only a mild reduction of the uncrossed pathway. Since in these studies the pathways were studied after the period of maximum cell death, it is possible that a significant carly reduction of the uncrossed pathway was obscured, as in the rat experiments reported here, by later differential cell losses.

\section{Differences between normally pigmented and albino animals}

The control, unoperated animals. Our results confirm that there is a difference between albino and normally pigmented animals, and that this difference is already present at birth in the rat (see Bunt et al., 1983) as it is in the cat and the ferret (Shatz and Kliot, 1982; Cucchiaro and Guillery, 1984; Morgan and Thompson, 1985; Cucchiaro, 1991). It is of some interest to 
note that at birth the albino rat has fewer ipsilaterally projecting cells not only in the temporal retina but across the whole of the retina. Figure 6 shows that there is a steeply graded difference across the retina, slight near the optic disk, gradually increasing toward the position of the normal border of the temporal retina, and then increasing markedly right up to the temporal periphery. That is, the albino gene can affect the early outgrowth of uncrossed fibers from all parts of the retina, not just the temporal retina. The subsequent postnatal loss is relatively greater for the nasal than the temporal retina in both types of rat, so that in the adult, binocular, rat the uncrossed component from the nasal retina is still smaller in the albino than in the normal rat.

In contrast to this, a comparison of normal and albino ferrets shows no difference in the nasal retina for the control group of animals, suggesting that the uncrossed pathway from the nasal retina in ferrets is more independent of the influence of the albino gene than it is in rats.

The enucleated animals. An earlier study by Godement et al (1987a) showed that the area occupied by the ipsilaterally projecting ganglion cells in the temporal retina of an adult mouse that had been monocularly enucleated at E12 or E13 appeared to be smaller than normal, resembling the condition that Dräger and Olsen (1980) had previously described for albino mice. In contrast to this, the relatively stable border of the temporal retina seen in association with very significant reductions in the numbers of ipsilaterally projecting ganglion cells in this study, appears to argue against the possibility that a monocular enucleation can shift this border. In the present study, in several pigmented ferrets in which the E27 enucleation had reduced the number of ipsilaterally projecting ganglion cells in the temporal retina to the levels characteristic of albinos, the position of the border was unaffected. Only in two of the E26 animals in which the number of ipsilaterally projecting ganglion cells was even more severely affected was there a shift in the border, and it is possible to argue that the shift demonstrated in mice by Godement and colleagues is comparable to this situation. We cannot make a precise comparison between the two species because we cannot judge at what stage in the reduction of the uncrossed pathway of mice the border begins to shift, nor can we assume that the relative values will be comparable in two different species. We can only stress that the enucleation can have a quite severe action on the uncrossed pathway without mimicking the albino effect of a shifted border, and that therefore the enucleation has an effect that is distinct from the albino effect. There may be a threshold value for the population of ipsilaterally projecting ganglion cells in the temporal retina below which the nasal border cannot be sustained in its normal position, and this appears to be distinct from the developmental process that produces the shift in albinos.

\section{The difference between the nasal and the ventrotemporal components}

The main uncrossed component that has been studied here arises from the ventrotemporal retina, and this is obviously reduced after the early monocular enucleations in both species. In the rats, the smaller uncrossed component that comes from the nasal retina has not been significantly reduced by the enucleation. This conclusion is based not only on the numbers of cells that survive in the adult rats, which are certainly affected by the relative severity of postnatal cell death, but is based also on the numbers obtained from neonatal animals. The ferrets show a reduction in the uncrossed projection from the nasal retina that is present at birth (Table 3), and this reduction appears to be greatest in the animals enucleated earliest. Possibly the enucleations in the rats were not done early enough to show this effect, but the possibility, raised below, that the control of the development of the nasal uncrossed component is not exactly the same in ferrets and rats, merits consideration.

Some of the uncrossed nasal fibers, probably more in the rat than in the ferret, may not be reacting to any specific guidance signal at the optic chiasm and may therefore be independent of the other retinofugal pathway. This idea is supported by the observation that a substantial number of fibers remain in the ipsilateral tract even in animals with one eye removed before any fibers have arrived at the chiasm (Sretavan and Shatz, 1986; Godcment et al., 1987a; Sretavan and Reichardt, 1993). That is, there may be two distinct populations of uncrossed fibers at the chiasm, one subject to binocular interactions, and the other not. Many, possibly all, of the latter are in the nasal retina and tend to die postnatally, and for this reason these fibers have often been treated as though they are an "error."

Clearly, any developmental feature that occurs consistently in all members of a species cannot reasonably be regarded as an error, but the forces that act to maintain such features during the course of development may well be quite different from those acting on structures that must be maintained through to the end of the developmental process. Seen in this light it may not be surprising to find that the reaction of the uncrossed nasal component to an early enucleation or to the action of the albino gene does not follow any easily defined rules in the two species. The nasal component may be governed by forces that also act upon the temporal component, or the two may interact with each other in a competitive manner, either along the pathway or within the terminal relays. These are problems that remain to be defined, but until they are we will not be in a position to have a clear understanding of processes that have produced all of the complex changes in the uncrossed nasal components of our experimental rats and ferrets.

\section{The timing of the enucleation effect}

Godement et al. (1987a) showed in mice that the earlier an enucleation is carried out, the more severe is the reduction of the uncrossed component of the retinofugal pathway. We have found the same in ferrets. In mice an E12 enucleation produced a more severe effect than an E13 enucleation, and in ferrets, the enucleations at E26 and E27 were progressively more severe than the E28 enucleations. Since the first retinofugal axons reach the optic chiasm before E13 in mice (Godement ct al., 1987b) and on E23 or E24 in ferrets (Guillery and Walsh, 1987), the easiest interpretation is that only fibers reaching the chiasm after the enucleation are unable to enter the ipsilateral optic tract, and that earlier arrivals survive relatively unscathed. The tendency for the uncrossed component of monocularly enucleated ferrets to lose a significant number of cells from the peripheral parts of the temporal retina (the right shoulders of the plots in Fig. 12) would be in accord with this interpretation, if one assumes that in the ferret, as in the cat (Walsh et al., 1983), the peripheral parts of the retina develop relatively late. As an extreme view one could think that the differences between the several plots of Figure 12 provide some representation of how the ipsilaterally projecting ganglion cells are added to the temporal retina of ferrets over time.

The changes seen in the nasal retina after an early enucleation in ferrets are relevant because they suggest that some of the 
ipsilaterally projecting ganglion cells in the nasal retina (the ones modified by the enucleation) reach the optic chiasm relatively late. Since we have been unable to classify the ferret's ganglion cells in the newborn retinas in terms of their adult cell sizes, we cannot say which of the ganglion cell classes is most severely affected in the nasal retina. However, in view of the evidence that W-cells are born relatively late (Walsh et al., 1983), and that late-born ganglion cells having uncrossed axons die postnatally, it is probable that these are the nasal cells affected by the enucleation.

One serious difficulty with the above view is that the earliest fibers to reach the chiasm and enter the ipsilateral optic tract do not come from the temporal crescent, but come from the dorsocentral retina (Godement et al., 1987b; Colello and Guillery, 1990). The cells in the temporal crescent cannot be reached by retrograde markers from the ipsilateral tract until about E16.5 in mice (Colello and Guillery, 1990) and until about E28 in ferrets (Baker and Reese, 1993). This implies that the early enucleations done at E12 in mice (Godement et al, 1987a) or at E26 in normally pigmented ferrets would have been done at a stage when axons from the temporal crescent have probably not yet reached the optic tract, or even the optic chiasm. It is necessary to conclude that some axons can continue to enter the uncrossed pathway after the monocular enucleation, but that the enucleation reduces the chances for an axon to take an uncrossed course. This reduction appears to be more severe for peripheral, probably later-born, ganglion cells than for the more centrally placed ganglion cells of the temporal retina and may not affect the earliest dorsocentral component at all (see also Sretavan and Reichardt, 1993).

A second problem that needs to be addressed is that Sretavan and Shatz (1986) have described very early enucleations in cats. Developmental stages in cats and ferrets are roughly equivalent (cf. Shatz, 1983; Cucchiaro and Guillery, 1984), and Sretavan and Shatz made their enucleations at E23, a stage when no fibers have yet reached the chiasm. Their animals survived until about E59, a developmental stage beyond that of the ferrets studied here, but not beyond that of the adult mice studied by Godement ct al. (1987a). Sretavan and Shatz found an uncrossed component that was somewhat smaller than normal but that still had terminals occupying a significant portion of the lateral geniculate nucleus, far more than would be expected from an extrapolation of the ferret results reported here and by Guillery (1989).

At present we have no simple explanation for this discrepancy, although it may provide an important clue to understanding the development of the optic chiasm. The role of cell death occurring before E59 in the Sretavan and Shatz experiments was raised above; there is also a possibility that degeneration products may play a role in the enucleation effect. Possibly the earliest enucleations produce so little degenerative change at the optic chiasm that the uncrossed pathway is not seriously affected. However, the early enucleations reported by Godement at al. (1987a) would argue against this, as would the fact that in mice and ferrets the severity of the enucleation effect clearly increases as the enucleations are done earlier.

For the very early enucleations done by Sretavan and Shatz in cats we know the geniculate terminations, but we do not know the retinal origins of the uncrossed component. Since our earliest enucleations prevented the development of a temporal crescent, it is entirely possible that the uncrossed component in the cats described by Sretavan and Shatz came largely from nasal retina, and that this represents the early uncrossed com- ponent from the dorsocentral retina, which may develop unusually strongly when the other eye is removed early enough. The surviving temporal crescent described in mice after a very early monocular enucleation by Sretavan and Reichardt (1993) would argue against this, but since this result appears to contradict the effect of early enucleations reported by Godement et al. (1987a), also in mice, the issue must, at present, remain unresolved.

\section{The action of the early enucleation}

An early enucleation produces a reduced uncrossed pathway in mice, rats, and ferrets, but apparently not in marsupials (see above) or frogs (Kennard, 1981; Hoskins and Grobstein, 1985; Taylor and Gaze, 1990). Possibly the developmental mechanisms that produce the normal uncrossed pathway are quite different. In frogs the uncrossed pathway appears relatively late, after the crossed pathway is well established, and there is evidence that in marsupials the uncrossed fibers segregate from the crossed component at a prechiasmatic site (Jeffery and Harman, 1992; Guillery and Taylor, 1993), where binocular interactions are not likely to occur. However, we have noted above that a critical experiment for the marsupials would involve an evaluation of the enucleation effect before the period of normal cell death.

The mechanisms that produce the binocular interactions demonstrated by the early enucleations are not understood. It is possible that the process by which the uncrossed fibers are sorted from the crossed is the same throughout development. However, since the cells of the early dorsocentral uncrossed component appear to be randomly scattered in the nasal retina among the cells of the crossed component, whereas the later ventrotemporal cells are clearly segregated, one must regard the later uncrossed fibers as responding at the chiasm by a specific mechanism, which is particularly strongly expressed in the ventrotemporal crescent (see Wizenmann et al., 1993), but one can think of the early component as possibly entering the ipsilateral tract on a nonselective or random basis.

Godement et al. (1987b, 1990) have shown that in the mouse the early crossed fibers continue straight across the midline at the chiasm, whereas the uncrossed fibers all turn before they reach the midline, displaying rather complex growth cones at the turning point and then joining the crossed component from the other eye. Based on these results and on the effects of an early enucleation, Godement et al. (1990) have suggested that the pathfinding of uncrossed fibers at the chiasm may be a twostep process. The growing fibers may at first recognize cues about $100 \mu \mathrm{m}$ lateral to the midline that stop the further progress of uncrossed fibers but allow the crossed fibers to get through. These cues are thought to arise from the midline glia. The path of the uncrossed fibers is then determined by their selective fasciculation with the crossed fibers from the other eye, the latter serving to turn and guide the uncrossed fibers to the ipsilateral tract. No distinction between the early and the late components was proposed.

The effects of the prenatal enucleations would fit with such a scenario, but at present there is not enough evidence available to choose between this and alternative explanations of how the enucleation might act upon the early development of the uncrossed pathway. It is possible that the crossed fibers play a role in determining the course of the uncrossed fibers, but this may be because the crossing fibers modify the midline glia on their way across the midline, making the glia into a barrier for the 
putative uncrossed fibers; it may be that the crossing fibers are changed as they pass through the midline glia (see, e.g., Dodd and Jessel, 1988), becoming attractive to the putative uncrossed fibers only after the midline crossing; or the dual mechanism outlined above may be active in normal development.

Godement et al. (1990), studying the abnormal development produced by prenatal enucleations showed that 2-3 $\mathrm{d}$ after an early (E13) monocular enucleation in a mouse, there are abnormally few ventrotemporal fibers in the ipsilateral optic tract. Most of them appear to have stalled at the chiasm, where they form a mass of fibers tipped with growth cones on the optic side of the chiasm. At the stage at which these enucleations were done (E13) some fibers had probably already reached the optic chiasm (Colello and Guillery, 1990; Godement et al., 1990), so the enucleation may have produced degenerative changes at the optic chiasm, and these could also be responsible for the changed growth pattern of the surviving uncrossed pathway.

Here, the point to be made is that the early enucleation of one eye may interfere with the development of the uncrossed pathway from the other eye by one of several possible mechanisms acting at the chiasm. The enucleation may interfere with one of the mechanisms of normal development proposed above, or the action of abnormal degeneration products may be responsible. Further, these several possibilities are not mutually exclusive, and may not be identical in mouse, rat, ferret, and cat. The total loss of a temporal crescent in the ferret is in sharp contrast to its survival in a mouse after even the earliest enucleation, and the details of the retinal origin of the surviving uncrossed pathway in cats remain to be defined. More detailed evidence about events that occur after the earliest enucleations, done before any fibers have reached the chiasm (cf. Sretavan and Shatz, 1986; Godement et al., 1987a; Sretavan and Reichardt, 1993) is needed to define the precise sequence of events.

\section{The pattern of the geniculate terminations in relation to the retinal distribution of their cells of origin}

Finally, it is of some interest to compare the distribution of the ipsilaterally projecting ganglion cells with the distribution of their geniculate terminals. In a normal ferret or cat the ganglion cells form a continuous population in the temporal retina and their geniculate terminals form a correspondingly continuous distribution in the lateral geniculate nucleus. In albino carnivores, the ipsilaterally projecting ganglion cells still form a continuous distribution although it is a smaller one, but the geniculate terminals now have a patchy distribution that can no longer be regarded as a faithful mapping of their retinal origins (Cooper and Pettigrew, 1979; Morgan et al., 1987). It could be argued that this breakup of the geniculate map is some specific effect to be associated with the albino abnormality. However, the evidence that after an early enucleation the geniculate terminals in normally pigmented ferrets form interrupted patches precisely comparable to those of albinos (Guillery, 1989) combined with the present evidence that these patches also arise from a nonpatchy retinal origin suggests that there is not a specific effect of the albino gene at work. Rather, it would appear that a reduction of the uncrossed component below a certain size prevents the development of a continuous geniculate mapping. Oddly, this occurs even though the uncrossed pathway in the monocular enucleates is not subject to any competitive interactions with another retinofugal pathway in the geniculate nucleus.

\section{Conclusions}

Whatever the mechanisms that are disrupted by the early enucleations, they are independent of those responsible for producing the characteristic albino abnormality. In addition to the developmental processes discussed above that may be active at the chiasm, one has to recognize that there are other processes active in the retina or distal eye stalk, at a site where the ventrotemporal ganglion cells or their fibers can be exposed to conditions that differentiate them from most (but not all) of the other retinofugal components. The albino gene appears to act upon these, not upon the chiasmatic processes discussed above. The characteristic action of the albino gene, of reducing the uncrossed component and shifting the nasal border of the temporal retina, can still be expressed after an early monocular enucleation. We conclude that even though an early enucleation and the albino gene produce reductions of the uncrossed pathways that resemble each other in terms of the pattern of distributions of geniculate terminals in ferrets, and in terms of the number of uncrossed fibers that develop in mice, those resemblances cannot be explained by the same set of developmental processes. The enucleation is likely to act at the chiasm whereas the albino gene probably acts in the eye.

\section{References}

Baker GE, Reese BE (1993) The chiasmatic course of temporal retinal axons in the developing ferret. J Comp Neurol 330:95-104.

Bunt SM, Lund RD, Land PW (1983) Prenatal development of the optic projection in albino and hooded rats. Dev Brain Res 6:149168.

Chalupa LM, Lia B (1991) The nasotemporal division of retinal ganglion cells with crossed and uncrossed projections in the fetal rhesus monkey. J Neurosci 11:191-202.

Chalupa LM, Williams RW (1984) Prenatal development and reorganization in the visual system of the cat. In: Development of visual pathways in mammals (Stone J, Dreher B, Rapaport DH, eds), pp 89-102. New York: Liss.

Chan SO (1991) Development of the mammalian retinofugal pathway. DPhil thesis, University of Oxford.

Chan SO, Jen LS (1988) Enlargement of uncrossed retinal projections in the albino rat: additive effects of neonatal eye removal and thalamectomy. Brain Res 461:163-168.

Chan SO, Chow KL, Jen LS (1989) Postnatal development of the ipsilaterally projecting retinal ganglion cells in normal rats and rats with neonatal lesions. Dev Brain Res 49:265-274.

Chan SO, Baker GE, Guillery RW (1993) Differential action of the albino mutation on two components of the rat's uncrossed retinofugal pathway. J Comp Neurol, in press.

Colello RJ, Guillery RW (1990) The early development of retinal ganglion cells with uncrossed axons in the mouse: retinal position and axonal course. Development 108:515-523.

Coleman L-A, Beazley LD (1989) Expanded retinofugal projections to the dorsal lateral geniculate nucleus and superior colliculus after unilateral enucleation in the wallaby Setonix brachyurus, quokka. Dev Brain Res 48:273-291.

Cooper ML, Pettigrew JD (1979) The retinothalamic pathways in Siamese cats. J Comp Neurol 187:313-348.

Cucchiaro J (1991) Early development of the retinal line of decussation in normal and albino ferrets. J Comp Neurol 312:193-206.

Cucchiaro J, Guillery RW (1984) The development of the retinogeniculate pathways in normal and albino ferrets. Proc R Soc Lond [Biol] 223:141-164.

Dodd J, Jessel TM (1988) Axon guidance and the patterning of neuronal projections in vertebrates. Science 242:692-699.

Dräger UC (1985) Birth dates of retinal ganglion cells giving rise to the crossed and uncrossed optic projections in the mouse. Proc R Soc Lond [iol] 224:57-77.

Dräger BC, Olsen JF (1980) Origins of crossed and uncrossed retinal projections in pigmented and albino mice. J Comp Neurol 191:383412. 
Godement P, Salaün J, Métin C (1987a) Fate of uncrossed retinal projections following early or late prenatal monocular enucleation in the mouse. J Comp Neurol 255:97-109.

Godement P, Vanselow J, Thanos S, Bonhoeffer F (1987b) A study in developing visual systems with a new method of staining neurones and their processes in fixed tissue. Development 101:697-713.

Godement P, Salaün J, Mason CA (1990) Retinal axon pathfinding in the optic chiasm: divergence of crossed and uncrossed fibers. Neuron 5:173-186.

Guillery RW (1989) Early monocular enucleations in foetal ferrets produce a decrease of uncrossed and an increase of crossed retinofugal components: a possible model for the albino abnormality. J Anat 164: $73-84$.

Guillery RW, Taylor JSH (1993) Different rates of axonal degeneration in the crossed and uncrossed retinofugal pathways of Monodelphis domestica. J Neurocytol, in press.

Guillery RW, Walsh C (1987) Changing glial organization relates to changing fiber order in the developing optic nerve of ferrets. J Comp Neurol 265:203-217.

Guillery RW, Jeffery G, Cattanach BM (1987) Abnormally high variability in the uncrossed retinofugal pathway of mice with albino mosaicism. Development 101:857-867.

Hanker JS, Yates PE, Metz CB, Rustioni A (1977) A new specific, sensitive and non-carcinogenic reagent for the demonstration of horseradish peroxidase. J Histochem 9:789-792.

Hoskins SG, Grobstein P (1985) Development of the ipsilateral retinothalamic projection in the frog Xenopus laevis. J Neurosci 5:911919.

Hsiao K (1984) Bilateral branching contributes minimally to the enhanced ipsilateral projection in monocular Syrian golden hamsters. J Neurosci 4:368-373.

Jeffery G (1984) Retinal ganglion cell death and terminal field retraction in the developing rodent visual system. Dev Brain Res 13:8196.

Jeffery G, Harman AM (1992) Distinctive pattern of organisation in the retinofugal pathway of a marsupial. II. Optic chiasm. J Comp Neurol 325:57-67.

Jeffery G, Perry VH (1982) Evidence for ganglion cell death during development of the ipsilateral retinal projection in the rat. Dev Brain Res 2:176-180.

Jen LS, So KF, Woo HH (1984) An anterograde HRP study of the retinocollicular pathways in normal hamsters and hamsters with one eye enucleated at birth. Brain Res 294:169-173.

Kennard C (1981) Factors involved in the development of ipsilateral retinothalamic projections in Xenopus laevis. J Embryol Exp Morphol 65:199-217.

LaVail JH, Nixon RA, Sidman RL (1978) Genetic control of retinal ganglion cell projections. J Comp Neurol 182:399-422.

Linden R, Serfaty CA (1985) Evidence for differential effects of terminal and dendritic competition upon developmental neuron death in the retina. Neuroscience 15:853-868.
Lund RD, Lund JS (1973) Reorganization of the retinotectal pathways in rats after neonatal retinal lesions. Exp Neurol 40:377-390.

Lund RD, Lund JS (1976) Plasticity in the developing visual system: the effects of retinal lesions made in young rats. J Comp Neurol 169: 133-154.

Lund RD, Cunningham TJ, Lund JS (1973) Modified optic projections after unilateral eye removal in young rats. Brain Behav Evol 8:5172 .

Mendez-Otero R, Rocha-Miranda CE, Carvaho-Dias E (1986) Effects of monocular enucleation at different stages of development on the uncrossed retino-collicular projection in the opossum. Dev Brain Res 27:101-108.

Morgan JE, Thompson ID (1985) The distribution of ipsilaterally projecting retinal ganglion cells in neonatal pigmented and albino ferrets. J Physiol (Lond) 369:35P.

Morgan JE, Henderson Z, Thompson ID (1987) Retinal decussation patterns in pigmented and albino ferrets. Neuroscience 20:519-535.

Reese BE, Colello RJ (1992) Neurogenesis in the retinal ganglion cell layer of the rat. Neuroscience 46:419-429.

Sanderson KJ, Guillery RW, Shackelford RM (1974) Congenitally abnormal visual pathways in mink (Mustela vison) with reduced pigment. J Comp Neurol 154:225-248.

Shatz CJ (1983) The prenatal development of the cat's retinogeniculate pathway. J Neurosci 3:482-499.

Shatz CJ, Kliot M (1982) Prenatal misrouting of the retinogeniculate pathway in Siamese cats. Nature 300:525-529.

Sretavan DW (1990) Specific routing of retinal ganglion cell axons at the mammalian optic chiasm during embryonic development. J Neurosci 10:1995-2007.

Sretavan DW, Reichardt LF (1993) Time-lapse video analysis of retinal ganglion cell pathfinding at the mammalian optic chiasm: growth cone guidance using intrinsic guidance cues. Neuron 10:761-777.

Sretavan DW, Shatz CJ (1986) Prenatal development of cat retinogeniculate axon arbors in the absence of binocular interactions. $J$ Neurosci 6:990-1003.

Stone J (1966) The naso-temporal division of the cat's retina. J Comp Neurol 126:585-600.

Stone J, Campion JE, Leicester J (1978) The nasotemporal division of retina in the Siamcsc cat. J Comp Ncurol 180:783-798.

Taylor JSH, Gaze RM (1990) The course of regenerating retinal axons in the frog chiasma: the influence of axons from the other eye. Anat Embryol (Berl) 181:405-412.

Walsh C, Polley EH, Hickey TL, Guillery RW (1983) Generation of cat retinal ganglion cells in relation to central pathways. Nature 302 : 611-614.

Wizenmann A, Thanos S, Boxberg YV, Bonhoeffer F (1993) Differential reaction of crossing and non-crossing rat retinal axons on cell membrane preparations from the chiasm midline: an in vitro study. Development 117:725-735. 